\title{
The waning stage of a greenstone belt: The Mesoarchaean Mosquito Creek Basin of the East Pilbara, Western Australia
}

\author{
Wouter Nijman*, Quintijn Clevis ${ }^{1}$, Sjoukje T. de Vries ${ }^{2}$ \\ Department of Sedimentology, Faculty of Geosciences, Utrecht University, Postbus 80021, 3508 TA Utrecht, The Netherlands
}

\section{A R T I C L E I N F O}

\section{Article history:}

Received 16 October 2009

Received in revised form 25 February 2010

Accepted 9 March 2010

\section{Keywords:}

Mesoarchaean

Pilbara Craton

Mosquito Creek Basin

Archaean sedimentary basins

Greenstone belt evolution

\begin{abstract}
A B S T R A C T
The Mosquito Creek Basin stands apart in the Archaean granite-greenstone terrane of the east Pilbara Craton because of the rectangular outcrop but crescent-shaped subcrop, and its composition of lowgrade metamorphic mainly turbiditic clastic sedimentary rocks. These sediments belong to the c. $2.9 \mathrm{Ga}$ Mosquito Creek Formation. Tectonic interpretations of the basin have varied from a simple synclinorium, to an accretionary prism, an extensional passive margin, and more recently into a rift basin separating the Kurrana Terrane from the East Pilbara Terrane (EPT).

Combined sedimentological and structural-geological investigations show coarse-clastic fan-delta marginal facies with stacked unconformities, rimming an E-W basin centre with predominantly finergrained mass flow-dominated sediments. A N-S traverse therefore contains a complete cross-section of the Mosquito Creek Basin, shortened to about 50\% of its original width by tight folding and thrusting. The basin fill shows one major FU sequence from fan-delta sandstone to distal turbidites, unconformably overlying an older, partially preserved clastic sequence of comparable facies. A large slump unit occupies the basin axis. The unconformities along the margins interfere with folding of the sediments which also influenced basin-centre turbiditic palaeocurrents.

The basin is interpreted as a near-symmetrical, underfilled, compressional, intramontane, clastic sedimentary basin unconformably superposed on a volcanic greenstone belt rock assemblage with enclosed low-angle shear zones. Compression started during sedimentation under conditions of net subsidence within a rim syncline between adjacent domes. This occurred after phases of low-angle extensional and compressional deformation of the substrate not related to the present-day geometry of the granitoid domes. The geological setting of the Mosquito Creek Basin does not differ fundamentally from that of other adjacent E-Woriented greenstone belts of the EPT. The basin is inferred to represent the last, stratigraphically uppermost, and because of subsequent erosion rarely preserved, stage of greenstone belt evolution.
\end{abstract}

(c) 2010 Elsevier B.V. All rights reserved.

\section{Introduction}

This paper deals with the sedimentary architecture and structural control of the Mosquito Creek (MC) Basin, a Mesoarchaean clastic sedimentary basin of the Pilbara Craton of Western Australia. The MC Basin is exposed in a rectangular outcrop, further indicated as the Mosquito Creek (MC) block (Fig. 1), which is unique in the granite dome/greenstone belt dominated outcrop patterns of the Archaean East Pilbara Terrane.

Superposition of clastic sediments on greenstones during the Archaean is known from the Pilbara (e.g. Lalla Rookh Basin, Krapez,

\footnotetext{
* Corresponding author. Tel.: +31 235283982.

E-mail addresses: wnijman@geo.uu.nl (W. Nijman), Quintijn.Clevis@shell.com (Q. Clevis)

1 Present address: Shell International Exploration and Production B.V., Kessler Park 1, 2288 GS Rijswijk, The Netherlands.

2 Present address: Horizon Energy Partners, Prinses Margrietplantsoen 81, 2595 BR The Hague, The Netherlands.
}

1984; Krapez and Barley, 1987; Mallina Basin, Smithies et al., 2001), and from South Africa, Zimbabwe, and Canada (De Wit and Ashwal, 1997; Eriksson et al., 1994). Generally, the clastic sediments lie unconformably on the greenstone successions that are composed of (ultra)mafic and to a lesser extent of felsic volcanic rocks, and of minor (volcano-)clastic sediments. The basin shape of the clastic sediments, the geological setting, and structural regime are quite differently interpreted.

The present study is based on detailed geological mapping, and on structural-geological and sedimentological analyses in key areas selected for the purpose of basin analysis.

\subsection{The Mosquito Creek block: an enigmatic unit in the Archaean Pilbara}

\subsubsection{Geologic setting and existing interpretations}

Van Kranendonk et al. (2002, 2006, 2007), distinguish five structural domains or terranes in the (North) Pilbara Craton (Fig. 1). North of the MC block, the rocks belong to the EPT (East Pilbara Ter- 


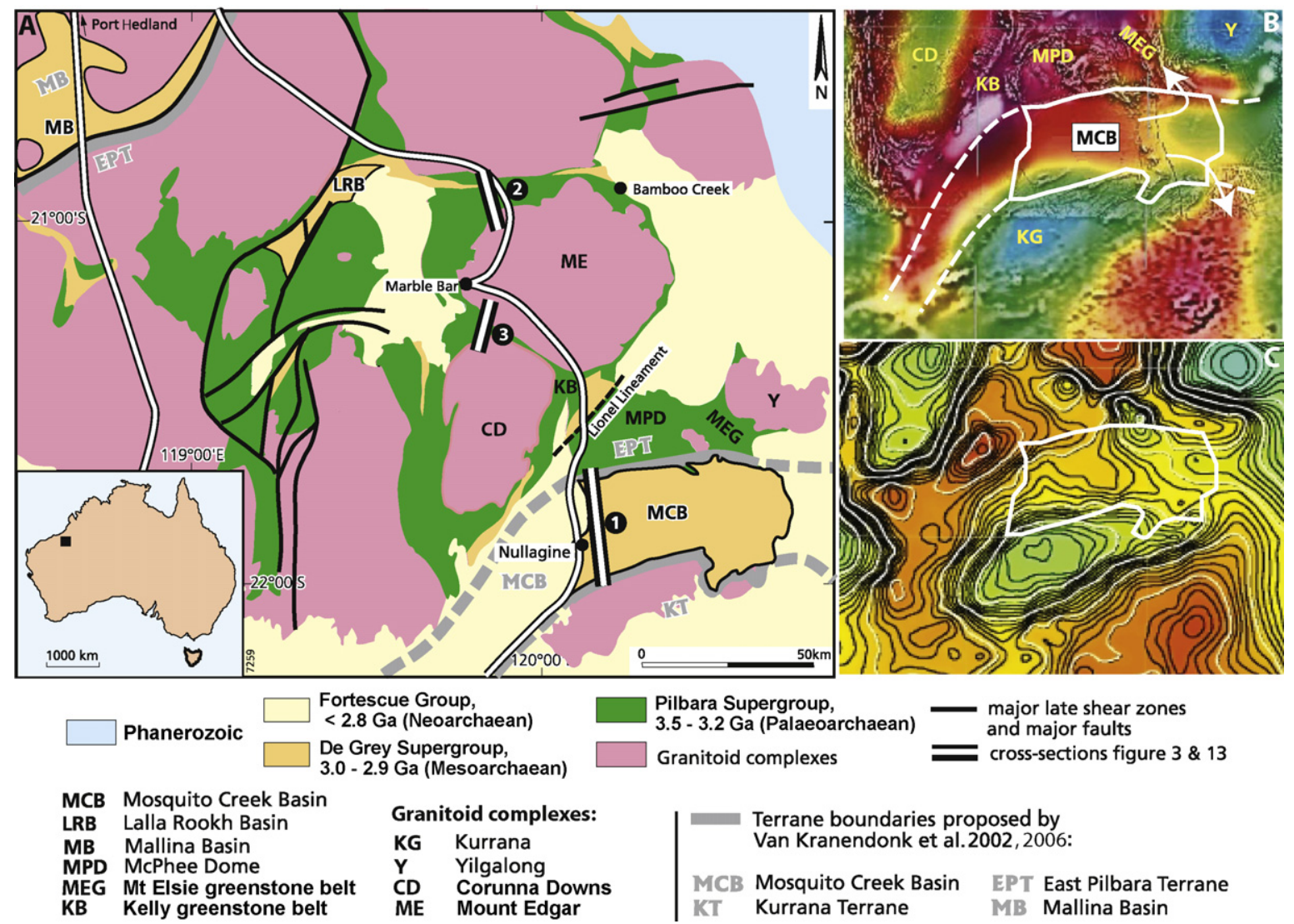

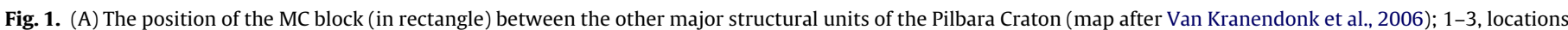

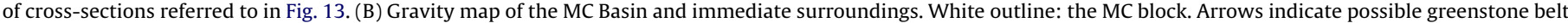

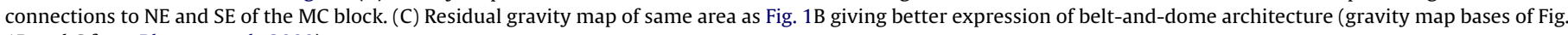
$1 \mathrm{~B}$ and $\mathrm{C}$ from Blewett et al., 2000).

rane, previously known as the East Pilbara GGT [granite-greenstone terrane]). The Kurrana granitoid complex, south of the MC block belongs to the Kurrana Terrane (KT). The MC block represents the visible part of a crescent-shaped domain, the MC Basin, well visible in the gravity maps of the area (Fig. 1a; Blewett et al., 2000), between the Kurrana Terrane and the EPT. Further to the NW in the Pilbara Craton and analogous to the MC Basin, the Mallina Basin separates the EPT from the West Pilbara Superterrane.

On the other hand, only three terranes have been distinguished by Blewett (2002) in the entire Pilbara Craton, the relatively young $(<3.27 \mathrm{Ga}$ ) West and Central Pilbara GGT's, and the older $(<3.65 \mathrm{Ga})$ East Pilbara GGT. He considered the latter as an older undivided dome-and-basin-structured terrane including the MC block and the Kurrana granitoid complex. Moreover, the gravity maps of the Pilbara Craton show a relative uniformity for the dome-and-belt architecture of the East Pilbara (Blewett et al., 2000; Wellman, 2000; cf. Fig. 1b and c). Recently, also Van Kranendonk et al. (2007) have expressed doubts about the Kurrana Terrane as a unit separate from the East Pilbara basement, based on the recalculation of data indicating Nd model ages in the typical range of EPT crust.

The MC block measures $60 \mathrm{~km}$ by 30 , and is at least partly faultbounded. The southern block boundary is a shear zone against the Kurrana granitoid complex (intrusion ages: 3283-3260 Ma, Tyler and Fletcher, 1992; 3190-3178 Ma and ca. $2838 \mathrm{Ma}$, Bagas et al., 2004b). The northern boundary separates the MC block in the northwest from the McPhee Dome, a domed greenstone complex, and in the northeast from the Mt Elsie greenstone belt and Yilgalong granitoid complex (ca. $3258 \mathrm{Ma}$, Farrell, 2006). In the recent 1: 100,000 and 1:250,000 geological maps (Bagas et al., 2004a; Bagas, 2005; Farrell, 2005, 2006; Williams and Hickman, 2007), this boundary is marked partly as a conglomerate-veneered unconformity and partly as a thrust fault.

The gravimetric map (Fig. 1b; Blewett et al., 2000) suggests that the northern greenstone basement and the southern granitoid basement of the MC Basin meet each other in a suture below the southern half of the MC block. The Mc Phee Dome is not the site of a gravity low (Fig. 1b), which precludes an important volume of granite at shallow crustal levels in the core of the structure (cf. North Pole Dome in Blewett et al., 2004). The McPhee Dome lies in the centre of the triangle formed by the Kelly, Yilgalong and MC belts (Fig. 1a). The doming may have been derived from the interference of sideward pressures exerted by the emplacement of the surrounding granitoid bodies, respectively the Corunna Down, Mount Edgar, Yilgalong, and Kurrana granitoid complexes.

The clastic sediments found in the MC block are tightly folded with fold axes parallel to the east-west axis of the block (Fig. 2). Thom et al. (1973) and Hickman (1978) interpreted the block as a synclinorium. Others considered both the northern and southern block boundaries as thrust faults, and the MC block as a thrust imbricate: either north block-up (Krapez, in Eriksson et al., 1994), or south block-up (Barley in De Wit and Ashwal, 1997; Barley and Pickard, 1999). More recently, up to 6 phases of deformation have been distinguished in the MC block, with the main phase of folding being represented by either the second one (Blewett, 2002) or the fourth one (Bagas, 2005) (NB in this paper the main-phase folding is indicated as D3; see Section 2.1). The most recent interpretation of the MC block by Bagas (2005; Bagas et al., 2008) is that of a north-facing thrust imbricate (his phase $\mathrm{D}_{\mathrm{MB} 4}$ ), which folds among others an extensional shear zone $\left(\mathrm{D}_{\mathrm{MB} 2}\right)$ along the contact with the Kurrana granitoid complex. Bagas (2005) found no evidence 


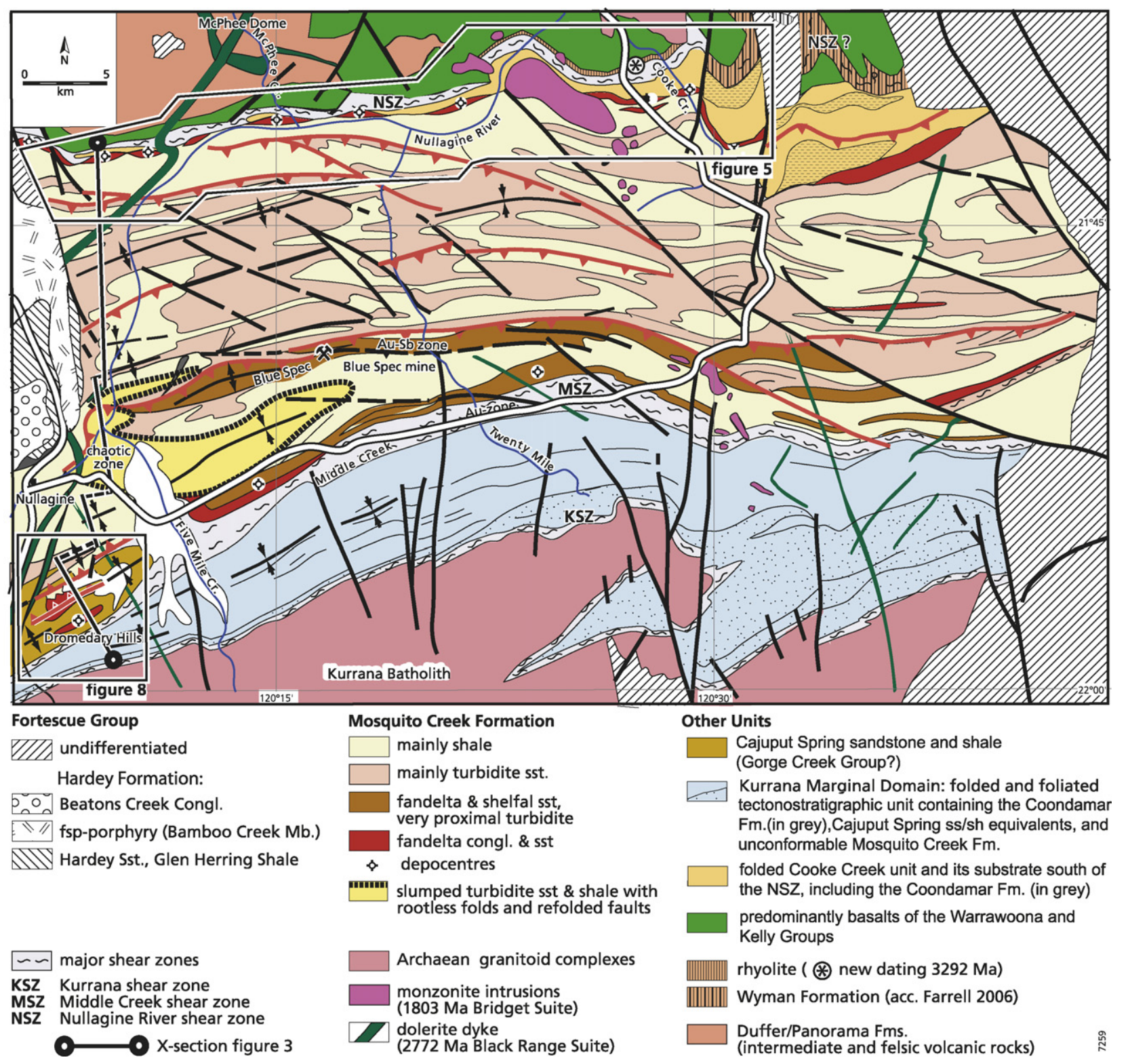

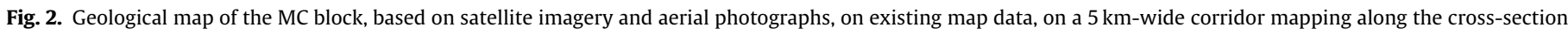

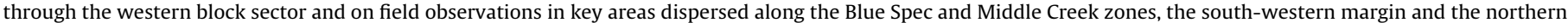
contact as far east as just beyond the Cooke Creek. Reference map to Fig. 3ff.

for synsedimentary tectonics, although he considers the extension along the Kurrana granitoid contact to be synchronous with the MCFm. Together with unpublished gravimetrical data this has led Bagas et al. (2008) to the preliminary concept that the MCFm was deposited in an extensional setting, presumably a rift basin. Van Kranendonk et al. $(2006,2007)$ place this rifting in the context of a series of extensional-compressional events spread over five clastic basins that constitute the De Grey Supergroup (see Section 1.1.3) generated after the accretionary history of the Pilbara Craton. These authors characterize the local main folding phase as the Mosquito Creek Orogeny (Van Kranendonk et al., 2006: their phase D10).

Two fold-parallel, in places intensely sheared, mineralized zones have been recognized and mined in the MC block: the Blue Spec and Middle Creek Au-bearing zones (Fig. 1a). The gold mineralization occurred at ca. $2905 \mathrm{Ma}$ and has been interpreted as syndeformational with the N-S shortening (Huston et al., 1999, 2002; Ferguson and Ruddock, 2001; Blewett et al., 2002; Bagas et al., 2008).

\subsubsection{The Mosquito Creek Formation}

According to Hickman $(1975,1978,1983)$ and Bagas (2005) the Mosquito Creek Formation (further indicated as MCFm) consists mainly of turbiditic sandstone and shale. Recently, the age of the MCFm was determined at between 2926 \pm 29 Ma (detrital zirkon age by Bagas et al., 2004b) and $2905 \pm 9 \mathrm{Ma} \mathrm{(Pb-Pb}$ model age of a lode gold mineralization in the MCFm in Thorpe et al., 1992) by Bagas et al. (2004b), and its lithostratigraphical position within the Nullagine Group of the De Grey Supergroup (see next section).

Sandstone and conglomerate are concentrated along the northern boundary of the MC block, in anticlinal cores in the centre, and locally in synclinal cores along the southeastern margin and the Middle Creek Zone. Sedimentologically, the central shaledominated has been first recognized as a turbidite sequence by Hickman $(1975,1978)$, which was linked up with a coarser-grained platform sequence further to the northwest in the east Pilbara by Eriksson (1981). Krapez [in Eriksson et al. (1994)] distinguished two 
structurally superposed clastic sequences, the lower in a forearc basin submarine-fan setting, the upper a coarsening-upwards (further abbreviated as $\mathrm{CU}$ ) fluviodeltaic sequence formed just before closure of the basin as a result of overthrusting by a granitoid body. Bagas et al. (2008), on the other hand, place the basin in a passive margin setting.

\subsubsection{Formations underlying the Mosquito Creek Formation}

In the 1:100,000 Nullagine map sheet, Bagas et al. (2004a) and Bagas (2005) distinguish a suite comprising a wide variety of rocks between the contact with the Kurrana granitoid complex in the south and the base of the MCFm. This rock suite includes komatiite, basalt, chlorite-actinolite schist, sandstone, siltstone, and chert. It is named the Coondamar Formation, Van Kranendonk et al. (2007) place the Coondamar Formation and the MCFm in the Nullagine Group. Together with other clastic sedimentary basin fills of the Pilbara Craton, respectively the Gorge Creek, Whim Creek, and Croydon Groups, the Nullagine Group is placed in the De Grey Supergroup, with an age range of ca. 3.02-2.93 Ma (Van Kranendonk et al., 2006). Because the Coondamar Formation is interleaved with the $3178 \pm 3$ Ma old Golden Eagle Gneiss, Farrell (2006) considers this to be the minimum age for this formation. Such an age does not correspond with that of the Nullagine Group but with the age of one of the formations in the upper part of the Pilbara Supergroup.

North of the MC block, i.e. in the McPhee Dome and Mt. Elsie greenstone belt, the ca. 3.35-3.27 Ma Kelly Group lies unconformably on the Warrawoona Group. It comprises amongst others the Euro Basalt (initially partly mapped as the now abandoned Copper Gorge Formation by Bagas, 2005). Farrell (2006) includes a wide variety of laterally discontinuous rock units, amongst others basalts and cherts, in an internally deformed Wyman Formation (i.e. part of the Kelly Group), which compositionally deviates considerably from its original definition as a mainly felsic (rhyolitic) volcanic unit (Lipple, 1975).

At present, it may only be concluded that between the Mosquito Creek Formation and the Kelly Group a folded and, in places severely sheared, volcano-sedimentary rock succession of variable composition has now been recognized, that includes rocks of the Kelly Group and the Coondamar Formation. The time interval involved is the period between $3310 \mathrm{Ma}$ (top of the Warrawoona Group according to Barley and Pickard, 1999) and 3178 Ma (Farrell's above-mentioned minimum age).

\subsubsection{The Neoarchaean cover sequence}

The MCFm is unconformably overlain by clastic sediments, basalt, and porphyry of the Fortescue Group (Nullagine and Mount Jope Supersequences of the Mount Bruce Supergroup: Blake, 1993; 2772-2715 Ma, Blake et al., 2004; Figs. 1a, 2, and 4). The studies of Blake et al. largely deal with the basin evolution from $2800 \mathrm{Ma}$ onward and the Neoarchaean rift setting for deposition of Fortescue Group. The depocentre evidently shifted westwards from the Mesoarchaean MC Basin into the Neoarchaean active rift basin of the Mt Bruce Supergroup. The latter was located along one of the major $\mathrm{N}$ to NE-oriented lineaments in the east Pilbara, the Lionel Lineament (Fig. 1a) (=Nullagine Lineament of Blake, 1993), a sinistral fault zone according to Krapez and Barley (1987), a relatively young dextral fault according to Van Kranendonk et al. (2002).

\subsection{Aim and methods}

Apart from the fact that little is known in detail about the geometry and filling of the Mosquito Creek Basin, its setting between other components of the GGT's of the Pilbara is questionable. Do the sedimentary rocks observed in the MC block form a thrust-deformed clastic suite deposited in a rift in a between two major terranes of the Pilbara Craton? Or does the basin represent the last, stratigraphically uppermost, and because of subsequent erosion rarely preserved stage of a greenstone belt evolution within one major GGT? Insight into the sedimentological character of the MC Basin and its synsedimentary tectonic control may contribute to finding an answer to such questions.

To this end a combined structural and sedimentological investigation has been undertaken consisting of:

(1) General mapping based on enlarged aerial photographs and on satellite images. Interpretation of this material, comparison with published maps (Bagas et al., 2004a; Farrell, 2005), and detailed field observations in the western half of the MC block resulted in the map of Fig. 2 that serves as an index map for this article.

(2) 1:12,500 corridor mapping along a N-S traverse in the western sector of the MC block, where good exposure of both the southern and northern block boundaries and sufficient facies differentiation at very low metamorphic grade allow sedimentological interpretation.

(3) Construction of a structural cross-section through this sector of the block (Fig. 3).

(4) Observations on the occurrence and nature of unconformities along the northern, southern and western boundaries of the MC block and sedimentological analysis of the clastic sequences involved (Figs. 4-9).

(5) Sedimentological analysis of sedimentary sequences in the central parts of the corridor to establish basin fill trends and current patterns (Figs. 10-12).

(6) Comparison of the basin cross-section with that of other greenstone belts in the east Pilbara (Fig. 13).

(7) 3D-palinspastic reconstruction of the cross-segment of the MC Basin (Fig. 14) and interpretation of its geodynamic setting.

\section{Structural framework}

\subsection{Gross structural features of the N-S cross-section through the MC block}

The cross-section of Fig. 3 through the westernmost part of the MC block (compare Fig. 2) is based on several hundreds of structural observations including younging directions along the trace of the traverse and immediately along strike to it.

Tight chevron folding is the most prominent style of deformation. Axial planes dip generally steeply southwards; only in the southern part (Dromedary Hills, Fig. 3) the dip is to the north. In cross-section, this creates an asymmetric fan of folds in the MC block between the Kurrana granitoid complex in the south and the McPhee Dome in the north. Fold axes plunge variably to the west and/or to the east. In this article, this main-phase folding is labelled D3, thus reserving D1 and D2 for deformations preceding the deposition of the MCFm. A pervasive axial planar foliation is visible in fine-grained parts of the stratigraphical sequence.

The cross-section shows several shear zones and high-angle thrusts: from north to south, the Nullagine River Shear Zone [NSZ], Taylor Creek Thrust, Sandy Creek Thrust, Blue Spec Thrust, Dromedary Thrusts, Middle Creek Shear Zone [MSZ], and the Kurrana Shear Zone [KSZ] (nomenclature partly after Tyler and Fletcher, 1992; Bagas et al., 2004a; Farrell, 2005). In map view (Fig. 2), the strike of the major thrusts is slightly convex towards the north. The thrusts are dissected by a set of en-echelon dextral NW-SE faults.

The N-S cross-section (Fig. 3 ) is subdivided into several mainly thrust-bounded domains, from north to south respectively: 
NNW

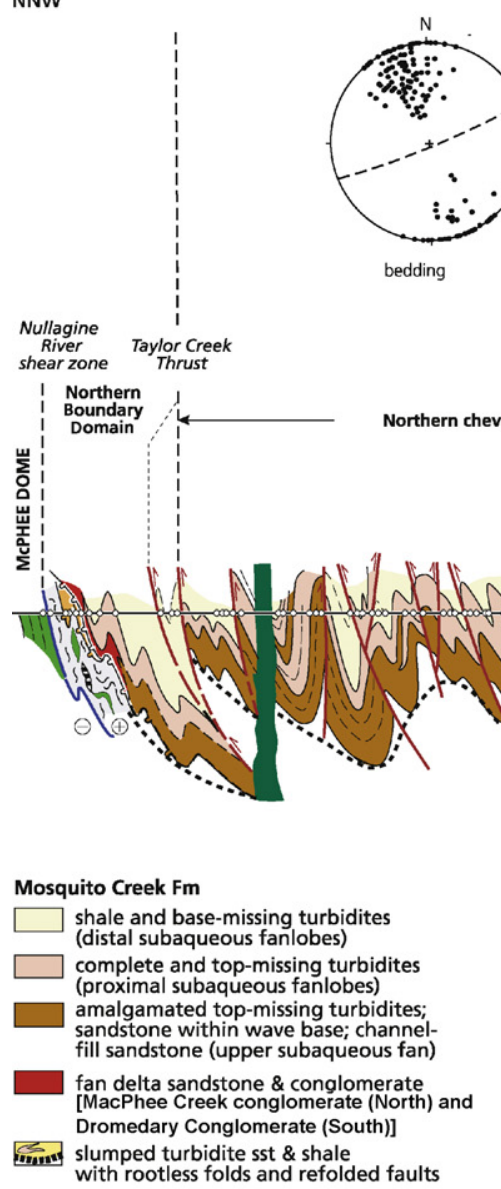

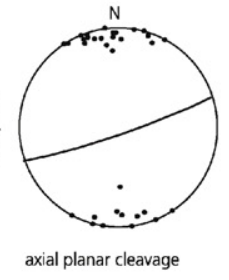

$\begin{array}{ll}\bullet & \text { Overturned beds } \\ \text { - normal younging }\end{array}$

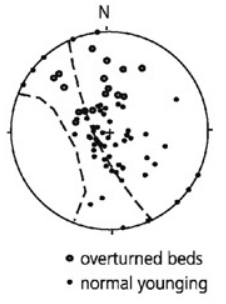

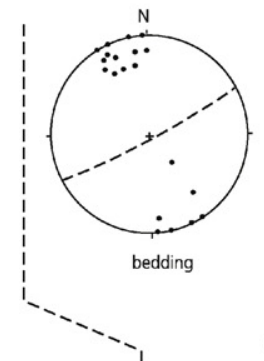

SSE

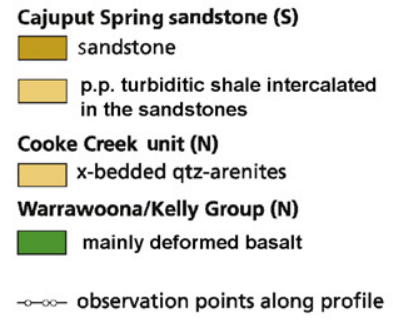

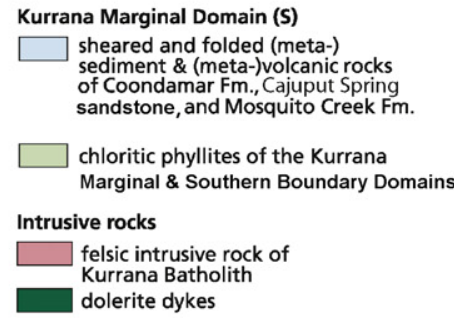

Shear zones

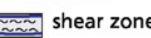

sheared, altered \& mineralized lenses of basalt \& ultramafics in

ali chert lense in shear zone

Anomalous contacts

$\sim$ unconformity

...... lower enveloping surface of fold pattern

slump fault system

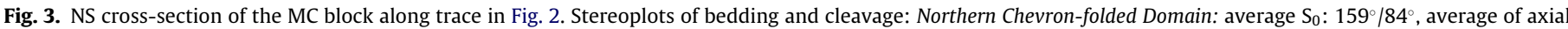

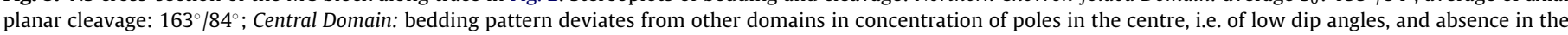

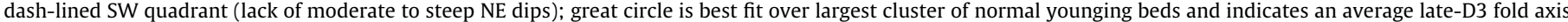

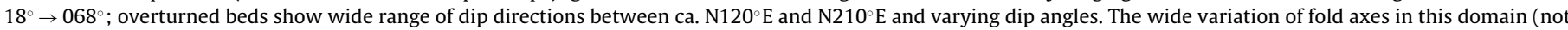

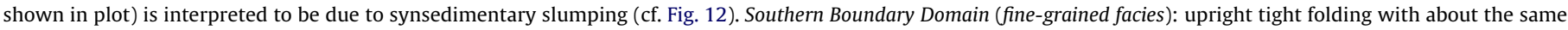

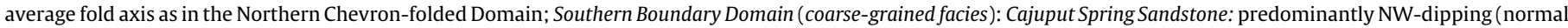

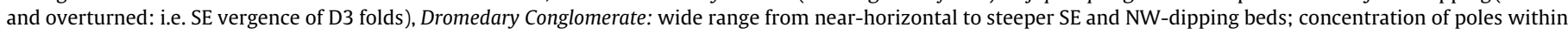

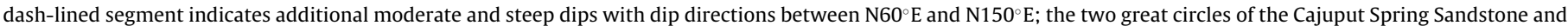
Dromedary Conglomerate almost coincide and point to a constant position of the average (=D3) fold axis at ca. $15^{\circ} \rightarrow 042^{\circ}$.

(1) The Northern Boundary Domain representing the northernmost thrust slice of the fold belt. This complex zone contains two superposed, and D3-folded, clastic suites (Fig. 4): the lower one is the Cooke Creek unit (new informal name), the upper one is the McPhee Creek conglomerate (new informal name) of the MCFm. Two unconformities separate these suites from each other and from the intensely deformed underlying basalt, komatiite and gabbro, and chert of the McPhee Dome. Notice that these two clastic suites differ from those distinguished by Krapez [in Eriksson et al., 1994] mentioned in the Introduction.

(2) The Northern Chevron-folded Domain is delimited to the north by the Taylor Creek Thrust and faulted by synthetic, and some antithetic, secondary D3-thrusts. It is, at least in the area of the traverse, predominantly composed of proximal turbidites.

(3) The Central Domain is represented by the Blue Spec Anticline flanked by the Northern and Southern Blue Spec Synclines. Both synclines expose predominantly distal turbidites and shale. The southern limb of the northern syncline is cut out by the Blue Spec Thrust. The Blue Spec Anticline exposes sandstone in its core towards the east. The anticlinal axis plunges westwards. The domain is further characterized by the occurrence of aberrantly low-dipping strata with recumbent and completely overturned, in places rootless, folds, and of low-angle shear zones.

(4) The Southern Boundary Domain comprises coarse-clastic facies within the southern segment of the fold belt. In several aspects this domain is the mirror image of the northern boundary zone. It consists of two superposed sandstone/conglomerate units (Fig. 4): the Cajuput Spring sandstone (new informal name after a well in the SW corner of the MC block, Fig $4 \mathrm{cf}$ Fig. 8a), and the Dromedary Conglomerate. Stacked unconformities postdate or interfere with generations of folds. Fold vergence is to the south. The MSZ separates this domain from:

(5) the Kurrana Marginal Domain, a folded and foliated tectonostratigraphic unit of meta-sedimentary and meta-volcanic rocks, including crenulated and kinked actinolite-chlorite phyllites, and metabasalt. The domain contains rocks of Cajuput Spring sandstone equivalent, the Coondamar Formation and the unconformably overlying MCFm. The contact between this zone and the southerly adjacent Kurrana granitoid complex is the KSZ.

The relative age of the main phase of deformation is constrained by the above-mentioned 2905 Ma dating of the syndeformational 


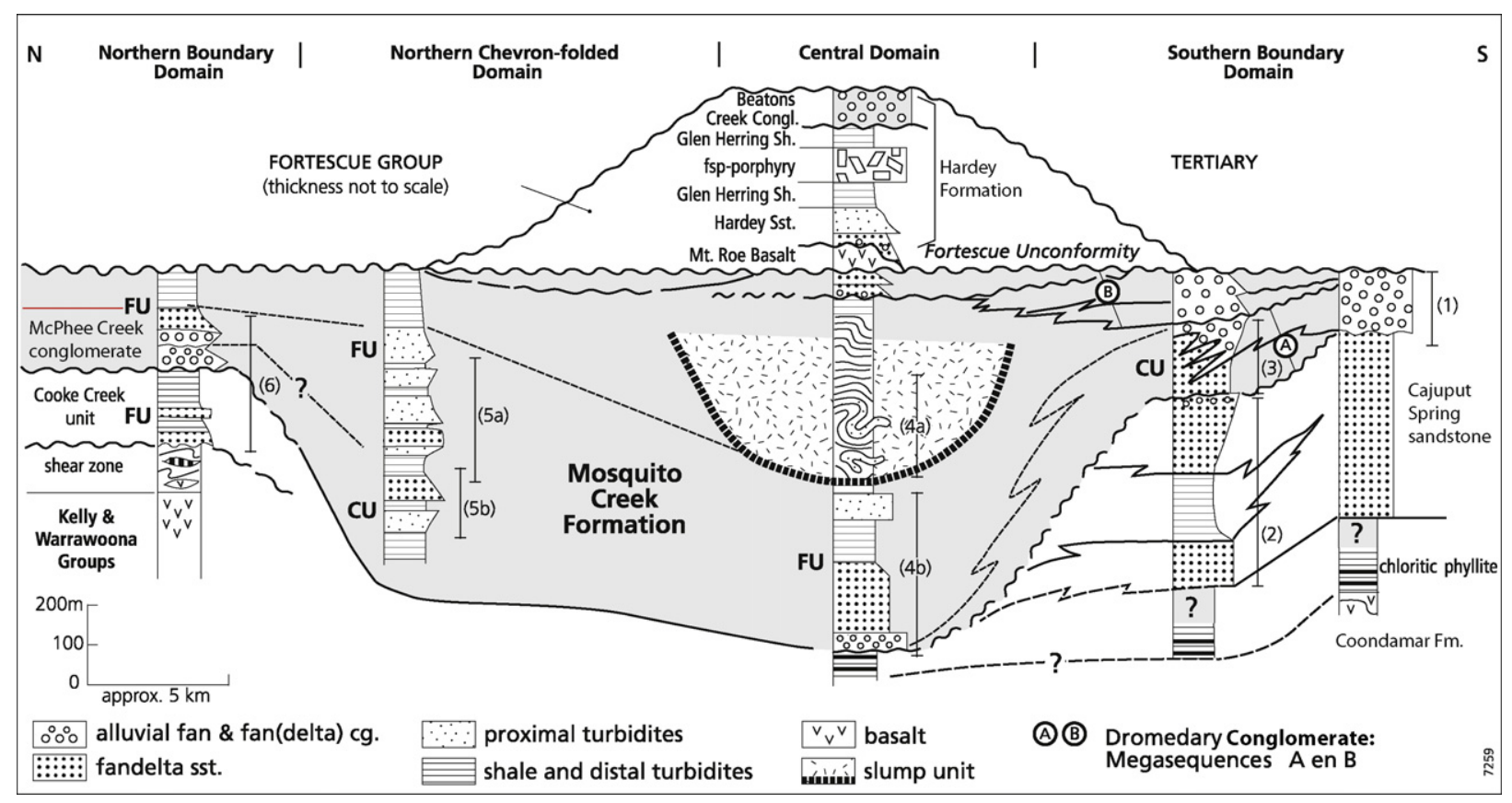

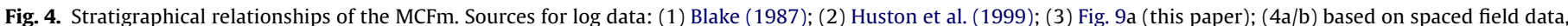
without continuous loggingi ; (5a) Fig. 10 (this paper), (5b) continuous log (not shown in this paper); (6) Fig. 7 (this paper).

gold deposits and by the occurrence of dykes of the Black Range Dolerite Suite (2772 $\pm 2 \mathrm{Ma}$, Wingate, 1999) which dissect the folded MCFm, but have been truncated by the unconformity below the Fortescue Group (Fig. 2).

\subsection{First inferences from the cross-section}

In interpreting the $\mathrm{N}-\mathrm{S}$ cross-section, one has to realise that its construction does not solely depend on structural-geological data. By far the better structural solution is given by the sedimentological analysis and correlation of the basin-fill sediments, in particular the coarse fraction as the basal part, discussed below. This allows the construction of a lower enveloping surface to the tight D3 fold pattern and the determination of the inferred position of the base of the basin fill.

First inferences from the cross-section are therefore:

(1) The lower enveloping surface of the D3 folds is itself folded into up to $3 \mathrm{~km}$-wide antiforms and synforms (cf. Hickman, 1978).

(2) The position of the so-defined base of the basin fill sequence is just above or in the Middle Creek zone and just below the Blue Spec zone (Figs. 2 and 3); till now both zones have been considered to be hosted entirely within the MCFm.

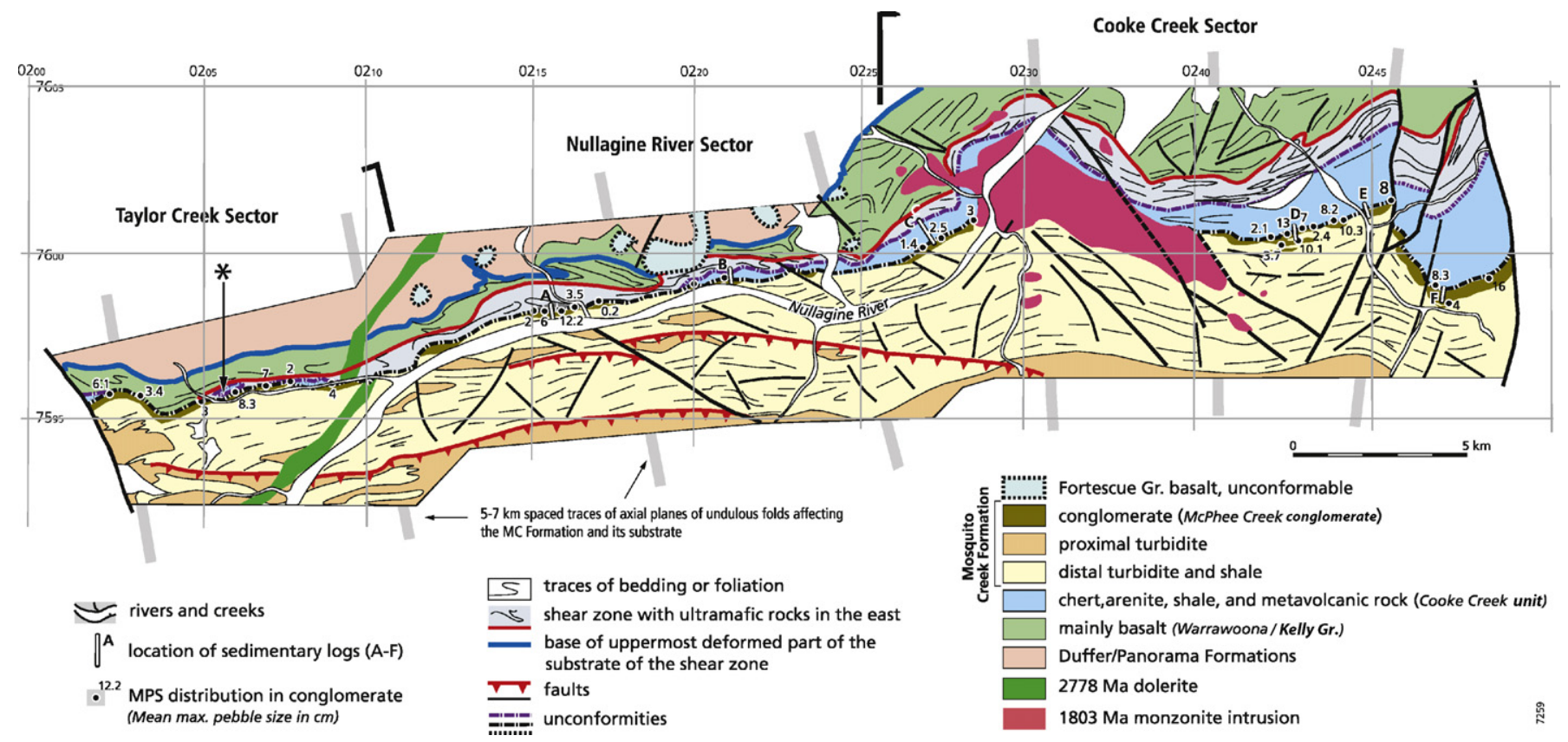

Fig. 5. Geological map of the central and western parts of the Northern Boundary Domain of the MC block. 
(3) The complex relationships in the Northern and Southern Boundary Domains, involving angular unconformities in the coarsest clastic sedimentary rocks, render the question relevant of what exactly is meant by the MCFm. Therefore, they deserve special attention.

(4) The amount of shortening over the profile is ca. $50 \%$, indicating an unfolded north-south $60 \mathrm{~km}$ width of the MC Basin.

\subsection{Post-D3 structures}

Minor vertical S-shaped and conjugate Z-shaped kinkfolds deform bedding and D3 axial planar cleavage. Associated are boudinage, $093^{\circ} / 66^{\circ}$ veins, and a new $110^{\circ} / 80^{\circ}$ fracture cleavage. Good examples of kink folds are found in the chlorite phyllites of the Kurrana Marginal Domain.

Late N-S faults and NW-SE faults contributed to the shaping of the Neoarchaean basins of the Pilbara Craton (cf. Huston et al., 1999; Blewett, 2002; Van Kranendonk et al., 2002). A N-S swarm of Proterozoic syenite/monzodiorite intrusions (known as the Bridget Suite and dated $1803 \pm 19 \mathrm{Ma}$, cf. Bagas, 2005) traverses the MC block in its centre.

\section{Delimiting the Mosquito Creek Basin}

\subsection{Basin-margin facies and unconformable relationships along the northern boundary}

Along the entire northern block contact (Fig. 2), conglomerates at the base of the MCFm unconformably overlie an association of faulted and folded basalt, ultramafic rock, felsic volcanic rock, banded chert, cross-bedded quartzose sandstone, and chloritic and micaceous shale. Most of these rocks occur within or next to a major shear zone, the NSZ (cf. Section 2.1). The conglomerates of the MCFm are here informally named the McPhee Creek conglomerate.

\subsubsection{The relationship of the McPhee Creek conglomerate with the NSZ}

Taylor Creek sector (Fig. 5; west): The $70^{\circ}$ south-dipping, otherwise undeformed, McPhee Creek conglomerate overlies highly sheared felsic volcanics, banded cherts and basalts (Fig. 6a), which occupy a broad zone along the southern side of the McPhee Dome, corresponding with the unassigned rock assemblage of Bagas et al. (2004a). At one location (* in Fig. 5), a tight, doubly plunging syncline in well-preserved cross-bedded quartzose sandstone (Fig. 6d) is unaffected by the shear deformation in the underlying basalt which indicates that the contact between the sandstone and the shear zone is a folded unconformity. Elsewhere (e.g. log site A in Fig. 5), the same sandstone also occurs immediately below the south-dipping conglomerate and with similar southerly dip. The shear zone truncates basalts and intermediate to felsic volcanic rock that constitute the bulk of the McPhee Dome in that area. According to Barley et al. (1998), the intermediate to felsic agglomerates and lavas compare petrologically with the Duffer Formation in the EPT. However, these rocks are assigned to the Panorama Formation by Bagas (2005) for chronological reasons, namely their 3433-3426 Ma age.

The sheared rock encases lenses ("fishes") of a variety of rock types in an anastomosing pattern. Riedel shear patterns and other brittle kinematic indicators point to a predominantly sinistral sense of motion. An opposite, dextral sense of displacement also occurs, though subordinately (see next section).

Nullagine River sector (Fig. 5; centre-west; $\log$ sites $A$ and B): The McPhee Creek conglomerate truncates a fining-upward (further abbreviated as FU) sequence of conglomerate to shale of the Cooke Creek unit (Fig. 6a), which in its turn unconformably overlies chert, and (ultra)mafic rock in an en-echelon array of fault slices, each southward younging. The latter emerge from a shear zone (the NSZ) in mafic and ultramafic rock of the Warrawoona Group with all the alteration characteristics (fuchsite, sericite, ankerite-mineral assemblage with sulphides), of such shear zones elsewhere in the east Pilbara (cf. De Vries et al., 2006). Foliation in the shear zone flattens from subvertical in the Taylor Creek sector to $179^{\circ} / 14^{\circ}$ near McPhee Creek (log site A in Fig. 5) a ${ }^{3} 153^{\circ} / 26^{\circ}$ further west $(\log$ site $B$ in Fig. 5$)^{b}$ and back to subvertical further eastwards. The foliation appears to follow the structural contours of the McPhee Dome and the Mt. Elsie greenstone belt. Fig. 6b shows a rootless subvertical S-fold in rhyolite within the sheared mafic and ultramafic rock, again indicating a sinistral sense of displacement at that location. Towards the east, the outcrop of the overlying McPhee Creek conglomerate diverges away from that of the shear zone. Stratigraphically, the space so created below the unconformity is occupied by a D3-folded tectono-stratigraphic unit, which comprises the Cooke Creek unit (Fig. 4) and its immediate substrate (p.p. metabasalts and cherts).

Cooke Creek sector (Fig. 5; centre-east): The lithological components found elsewhere isolated (see above) in the NSZ occur in a more orderly south-younging stratigraphical sequence at the exposures near Cooke Creek: pillowed basalt is respectively overlain by rhyolite, serpentinite and banded chert. The rhyolite ${ }^{c}$ is dated at $3292 \pm 3 \mathrm{Ma}$ (new Zr dating by Dr J.Wijbrans, Free University, Amsterdam). Nevertheless, here too, shear bands interrupt the rock succession. Although the major shear deformation is concentrated in a narrow band with serpentinite, other shear bands are scattered over a wide, intensily D3-folded zone with metabasalt, chloritic phyllite, crenulated shale, and quartzose sandstone. Further south, this rock assemblage is unconformably overlain by the south-dipping McPhee Creek conglomerate in CU/FU sequence (Figs. 4, 5 and 7).

Eastern Creek sector (east of gridline 246E in Fig. 5; cf. Fig. 2): The McPhee Creek conglomerate can be traced eastwards into the Eastern Creek area (Fig. 2). In Farrell's (2006) map the conglomerate is interpreted to have been thrust upon itself and upon the Coondamar Formation. The footwall of this thrust sequence lies unconformably on folded Wyman Formation (cf. Section 1.1.3) and unassigned Warrawoona Group rocks. In contrast to Farrell (2006), the map of Fig. 2 suggests the continuation of both the NSZ and the Cooke Creek unit into this sector.

\subsubsection{Sedimentological sequences and $3 D$-geometry of the northern basin-margin conglomerate}

Along the northern boundary, the McPhee Creek conglomerate crops out in a series of lenses (Figs. 2 and 5), not only where it truncates the shear zone in the west, but also in the more regular sequence to the east. The depocentres of these lenses correspond to grain size maxima. The pebble composition is dominated by banded chert, quartzose sandstone and basalt, all known from the local substrate. At log site D (Fig. 5), the palaeocurrent directions are downdip at almost right angles to the strike of the outcrop. For further sedimentological details we refer to Figs. 6 and 7. Fig. 5 also suggests a relationship between the repetition of conglomerate lenses and a faintly expressed structural undulation with $\mathrm{S}$ to SSE-striking vertical axial planes affecting the Northern Boundary Domain and its substrate.

3.1.3. Interpretation of the northern basin-margin configuration

(1) The angular-unconformable contacts of the Cooke Creek unit and the MCFm with the NSZ, and the changes in dip and strike of the shear foliation of the NSZ, absent in the overlying uncon-

\footnotetext{
3 Superscript markings 'a'-'r' refer to GPS locations in Appendix 1.
} 

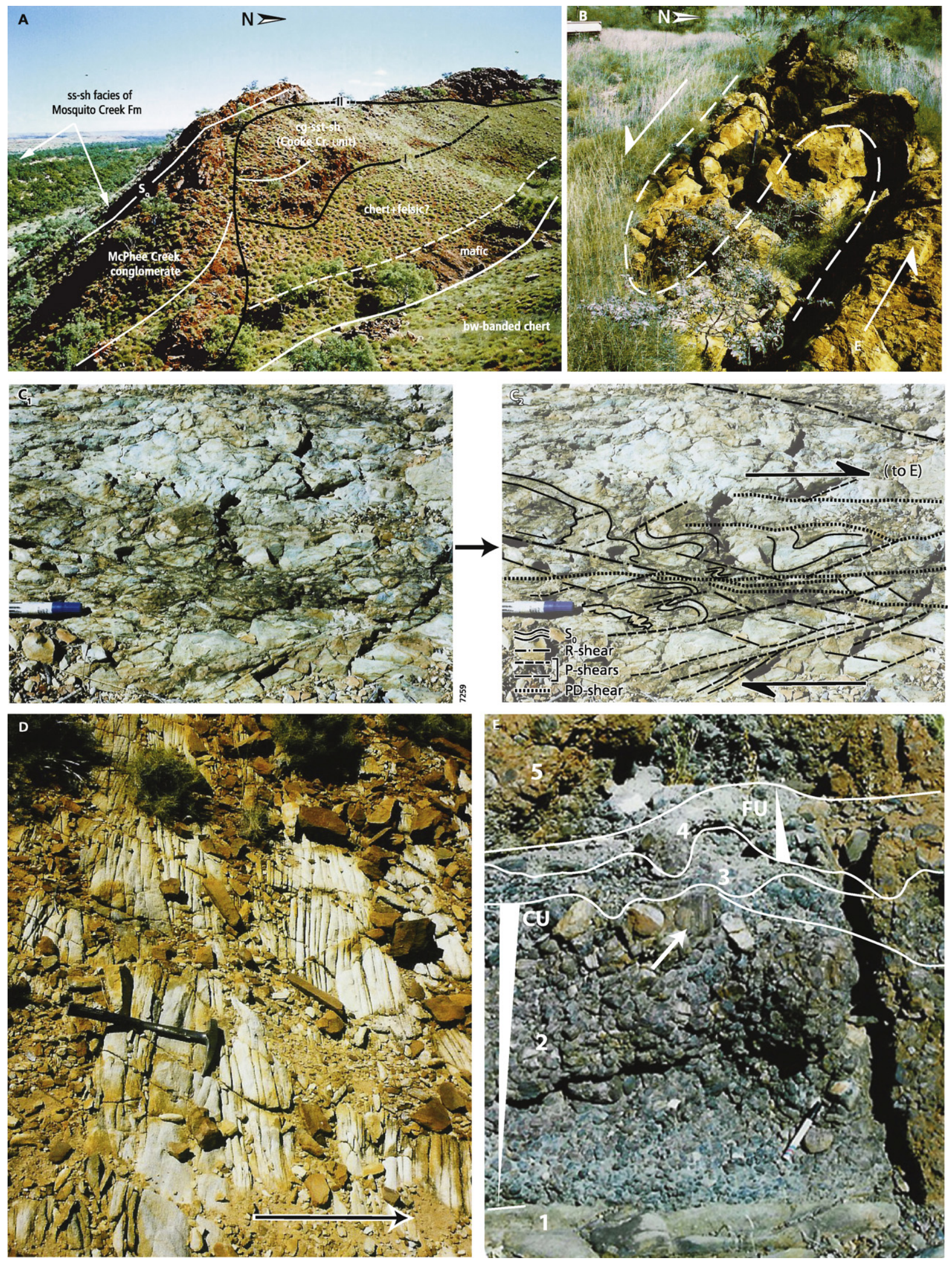

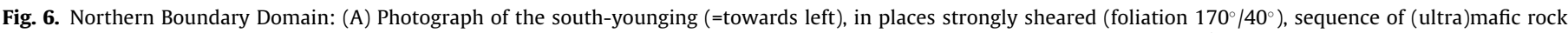

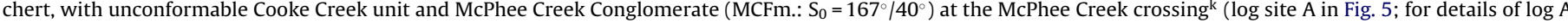

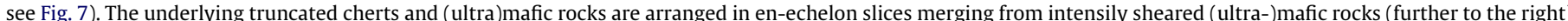

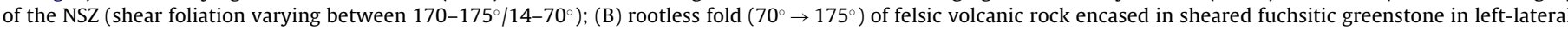

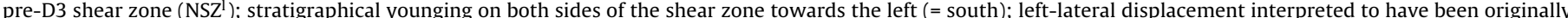

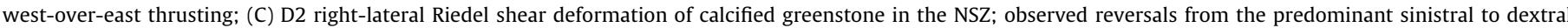

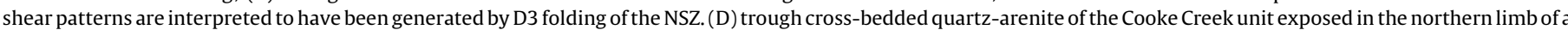



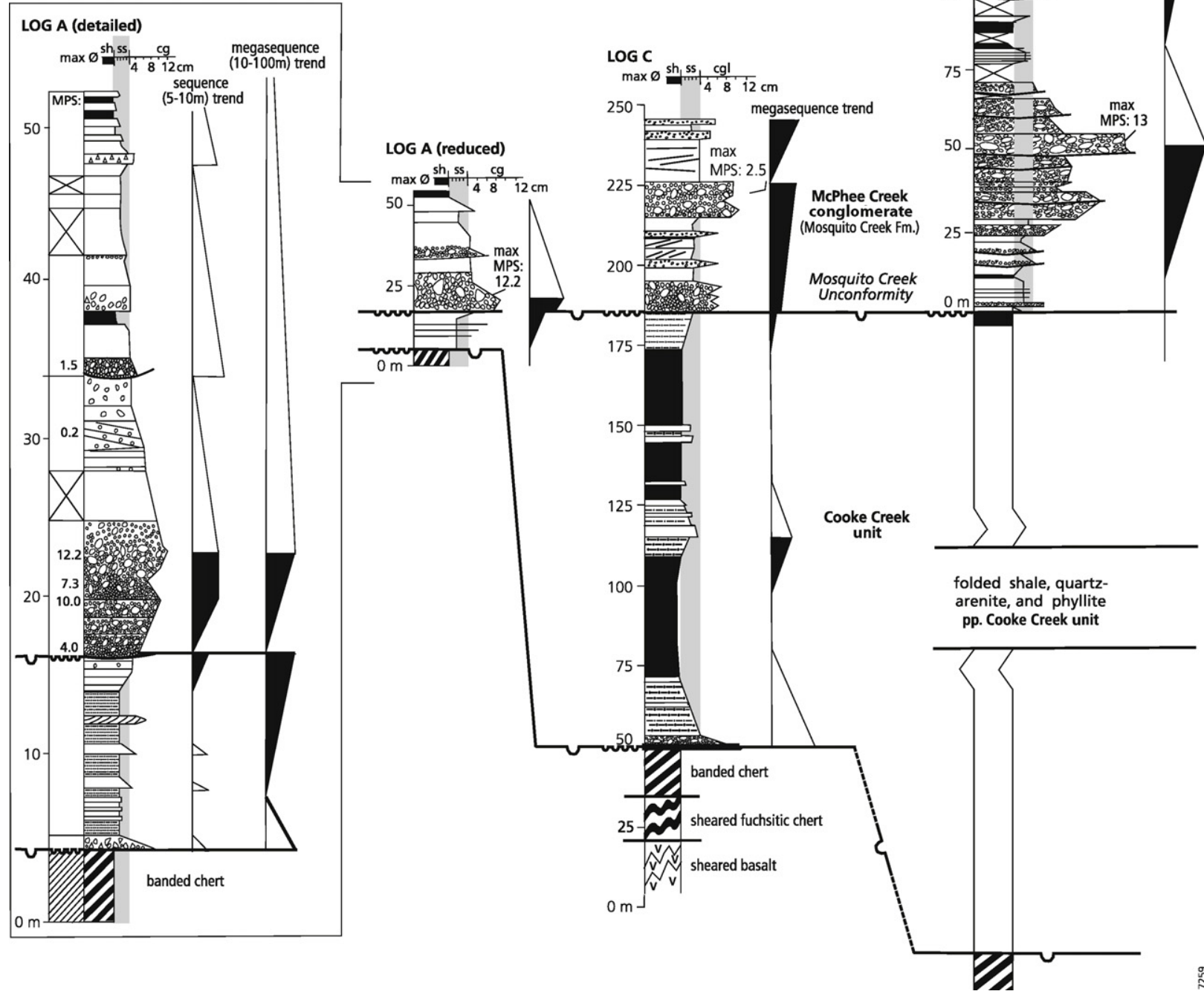

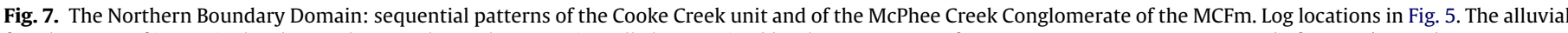

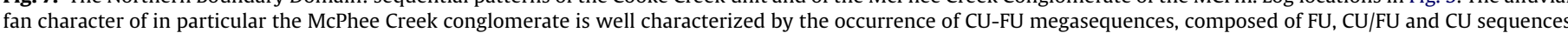

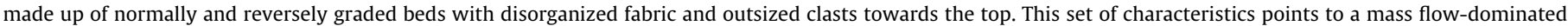
alluvial fan environment with high slope gradients as is often the case under intense structural control.

formable units, indicate that the shear zone has been tilted into its present position together with the greenstones during uplift of the McPhee Dome. The shear sense within the NSZ is predominantly sinistral, although dextral shear indicators have been observed as well. In places, D3-folds in the cherts within the shear zone and in the unconformable Cooke Creek unit indicate that the NSZ was also affected by this phase of folding and thrusting, which may account for the observed shear sense reversals.
Kinematic interpretation of the NSZ should take into account this evidence, and must therefore relate to its original attitude parallel or at low-angles to the bedding. Rotation of the NSZ into its pre-unconformity low-angle position changes the sinistral sense of motion into a west-over-east displacement. $\mathrm{Zr}$-dating of the rhyolite involved in the shear deformation sets a maximum age of $3292 \mathrm{Ma}$ to this low-angle (D2) deformation. The lithological heterogeneity and intense internal deformation within what is indicated by Farrell (2006) as the Wyman

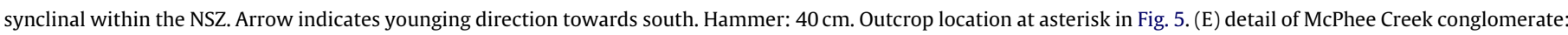

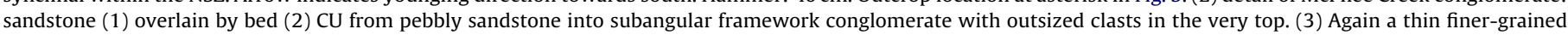

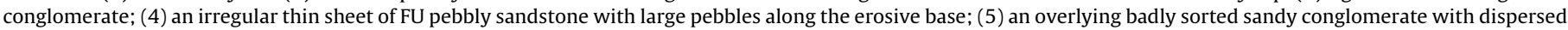

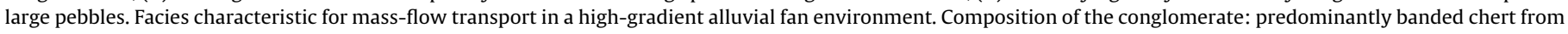
local substrate (pebble at arrow); Pencil: $14 \mathrm{~cm}$. Location: log site E in Fig. 5. 


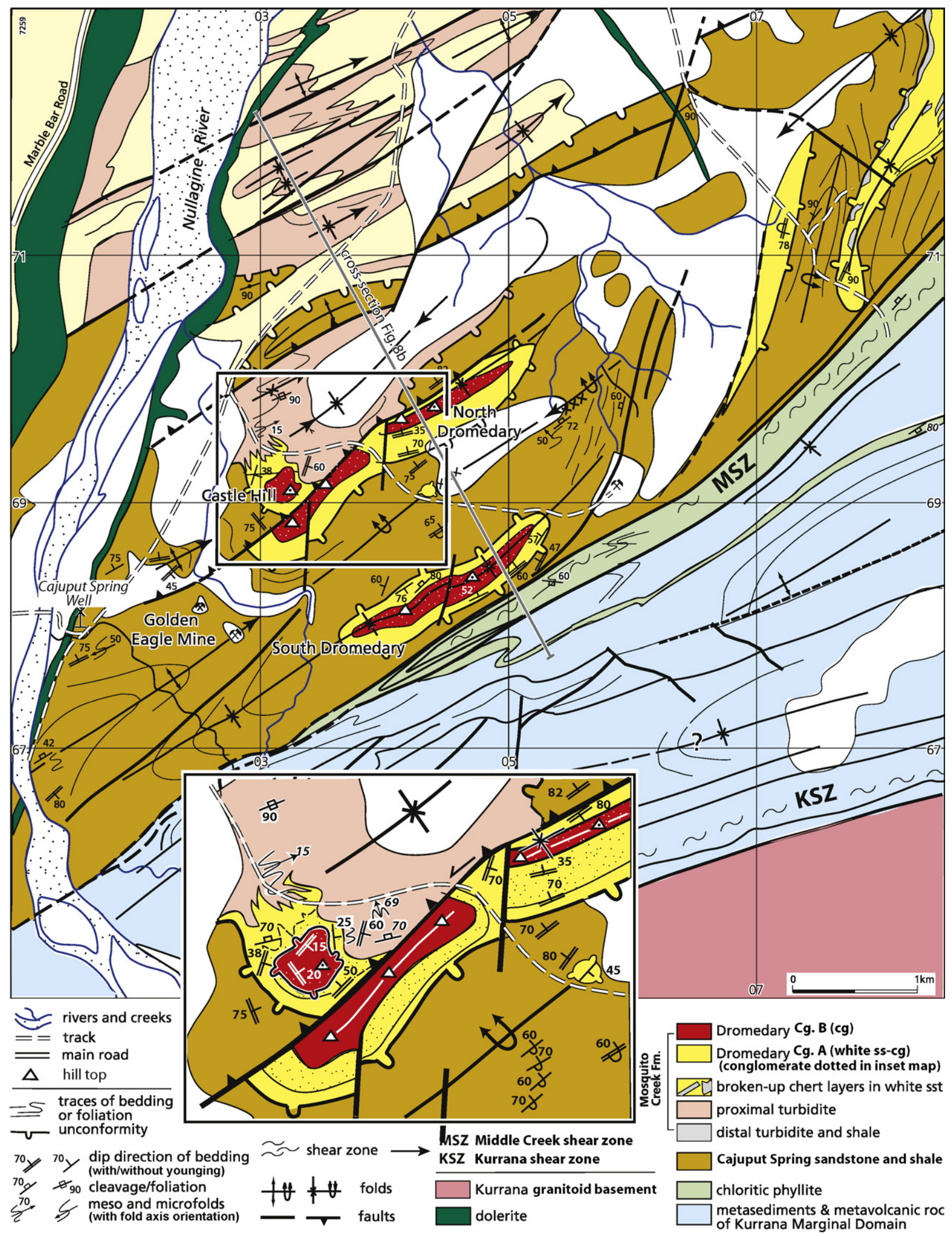

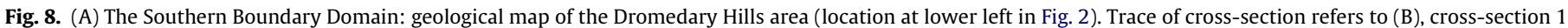

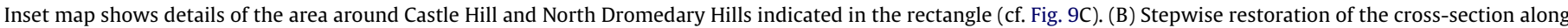

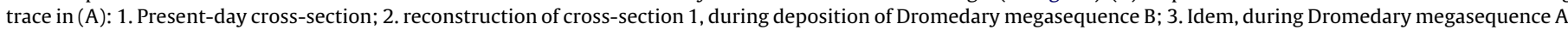

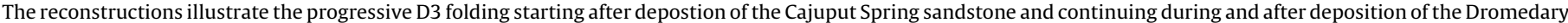
megasequences. 


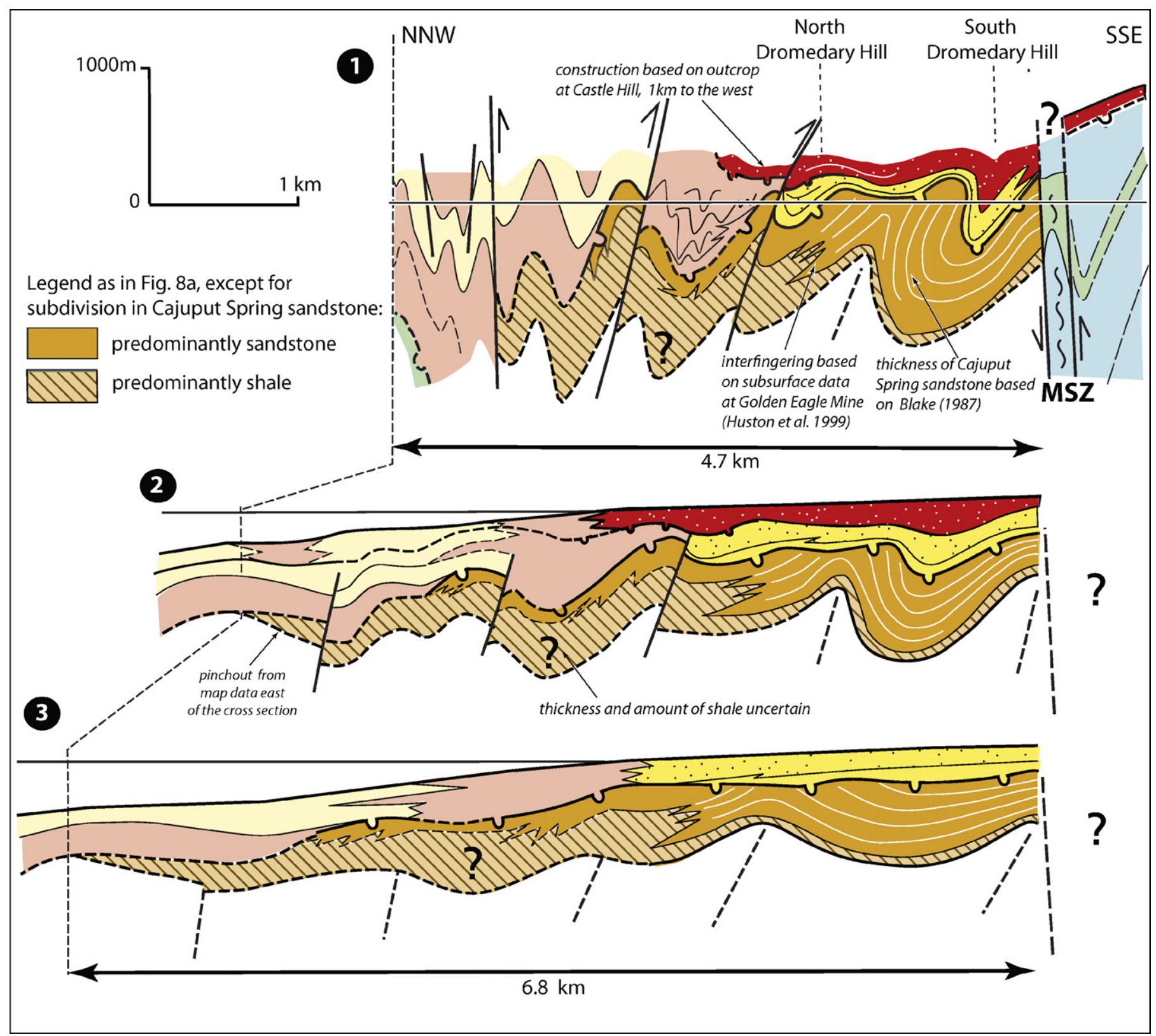

Fig. 8. (Continued).

Formation (see Section 3.1.1c), seem to match better with our definition of the NSZ as a shear zone subparallel to the bedding containing a mixture of rocks and following the structural contours of the northern basement of the Mosquito Creek Basin. It should be emphasized, however, that for sound conclusions on the deformation, the NSZ has to be studied in much more detail than has been possible within the framework of this study.

(2) The occurrence of the McPhee Creek conglomerate in laterally arranged lenses composed of stacked CU/FU megasequences (Fig. 7) is interpreted as an array of small alluvial fan-delta edifices along the original basin margin. A high-energy (mass flow-dominated) alluvial fan character is indicated in particular by the frequent presence of minor, single bed and decametre-scale, CU sequences (Fig. 6e), within the megasequential pattern (cf. Nemec and Steel, 1988). The FU trend from the fan deltas into the turbidite facies indicates submersion to base-of-slope conditions, indicative of conditions of underfill or over-subsidence in the basin.
(3) The faint structural undulation observed in the MCFm and its substrate is evidently younger than D3 and may reflect the differences in rock competence created by the fan edifices, during a later phase of east-west shortening.

\subsection{Basin-margin facies and progressive unconformities along the southern boundary (Dromedary Hills)}

\subsubsection{Geometry and structure of the southern margin}

The complex configuration around the North and South Dromedary Hills demands a detailed description. Map (Fig. 8a) and cross-sections (Fig. 8b) show an unconformable superposition of two clastic units: an arkosic sandstone-shale unit (the Cajuput Spring sandstone; Fig. 4) overlain by the Dromedary Conglomerate of the MCFm, itself composed of two superposed units (Fig. 9a): megasequence A, mainly sandy to conglomeratic; megasequence B, mainly coarsely conglomeratic (Fig. 4, fully exposed at North Dromedary and Castle Hills, Fig. 9b/c). Towards the north, this 

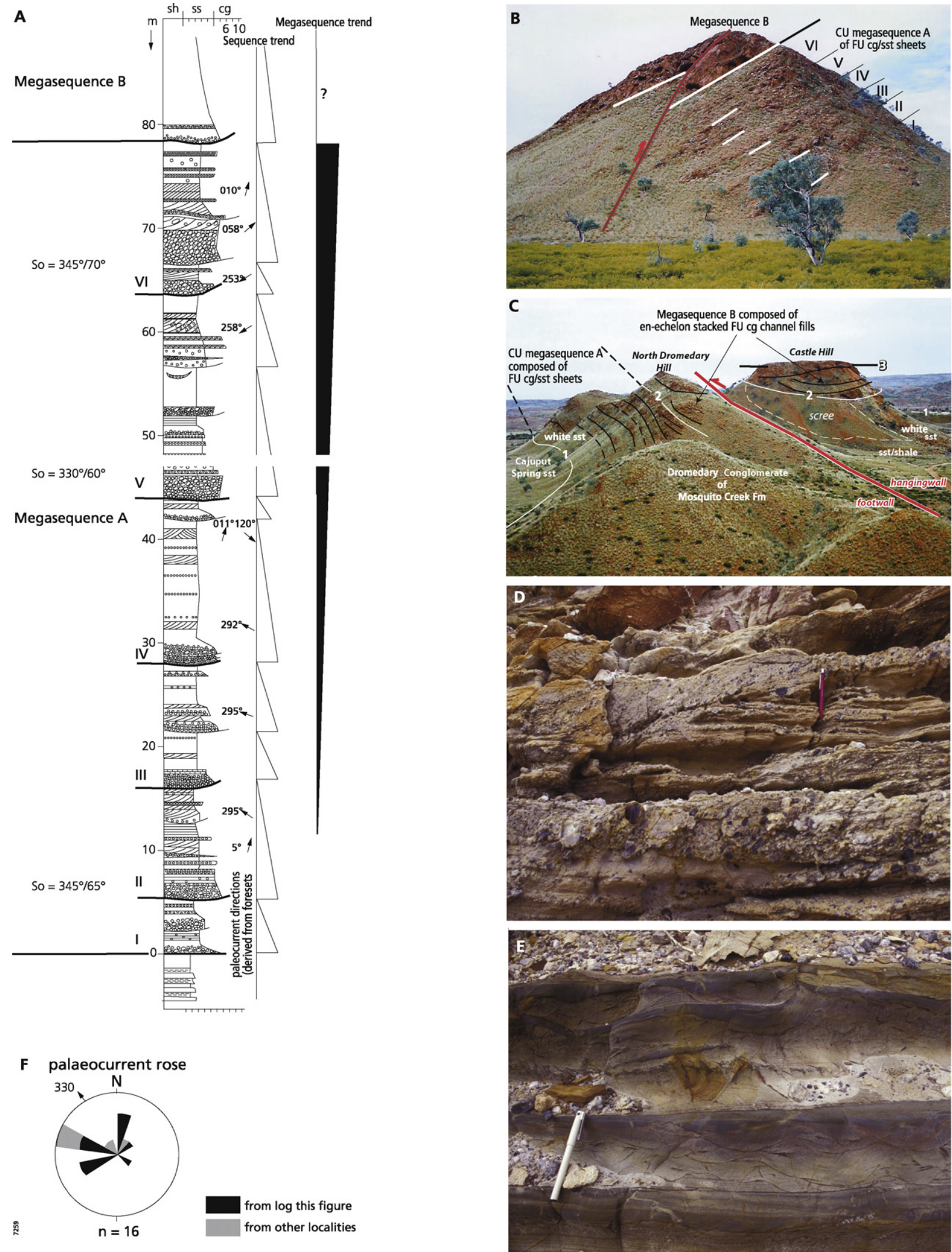

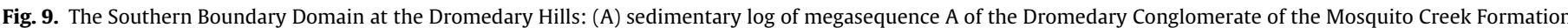

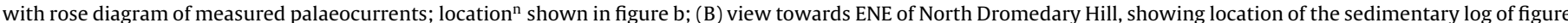

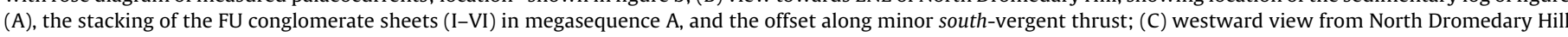

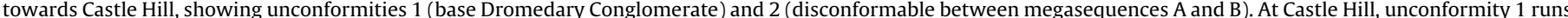

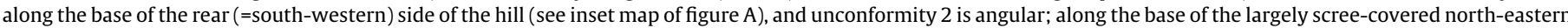

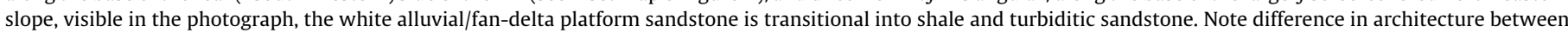

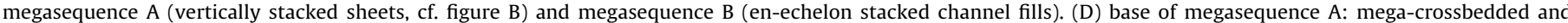


coarse-grained facies changes into turbiditic sandstone and shale within a distance of only one $\mathrm{km}\left(\right.$ Fig. $\left.8 \mathrm{~b}^{\mathrm{d}}\right)$. For the underlying Cajuput Spring sandstone a similar transition has been documented in a subsurface profile through the Golden Eagle gold mine (cf. Fig. 8b; Huston et al., 1999).

Both the Cajuput Spring sandstone and Dromedary Conglomerate, and the separating unconformity are asymmetrically folded (D3) with southerly vergence (Fig. 8b). Along North Dromedary Hill, the folding is accompanied by north block-up thrusting and stratigraphical duplication (Fig. 9b/c). In the direction of lateral facies change towards incompetent shale, the open folding in the $\mathrm{CU}$ part of the sequence changes into the tight chevron-folding characteristic of the D3 main phase of shortening elsewhere in the MCFm. Axial plunge is low (ca. $15^{\circ}$ ) to the NE (Fig. 8a). In places (quarry $1 \mathrm{~km} \mathrm{~N}$ of Castle Hill), intense axial planar foliation has resulted in transposition of the bedding.

It is important to note:

(1) that the unconformity between the Cajuput Spring sandstone and the Dromedary Conglomerate varies from a near-conformable contact in the syncline of South Dromedary Hill, to a low-angle contact at North Dromedary Hill, and a highangle contact in the intermediate anticline (Fig. 8b). D3-folding in this area therefore interfered with almost continuous deposition in the synclines and concurrent erosion in the anticlines, and may have started just before or during the formation of the unconformity.

(2) that at Castle Hill (Figs. 8a/b and 9c), a minor intraformational angular unconformity separates the more folded, much steeper dipping incomplete lower megasequence A of the Dromedary Conglomerate from the upper one B. This observation, too, provides clear evidence of the interference of compressive deformation with the sedimentation. At North Dromedary Hill, the lower megasequence is more complete (Fig. 9c). A southvergent thrust separates the two localities.

\subsubsection{Basin-margin sedimentology of the Dromedary Conglomerate}

Megasequence A starts with basal, white, even-laminated, and small-scale and megacross-bedded, quartzose sandstone with thin, often discontinuous sheets of disorganized conglomerate (Fig. 9d/e) with black chert pebbles. In places the cross-bedding is thixotropically deformed (Fig. 9e), contains greenish-coloured mud chips and drapes and reddish Fe-oxidized tops. North and eastwards the white sandstone gives way to shale with occasional turbidites (Fig. 8a: inset map, Figs. 8b, and 9c). In the North Dromedary Hills megasequence $\mathrm{A}$ is characteristically $\mathrm{CU}$ with an upwards increase of the amount of polymict conglomeratic sandstone and conglomerate (Fig. 9a). The latter are geometrically organized in vertically stacked, about $10 \mathrm{~m}$ thick, FU-sheets (Fig. 9a-c), that are not interconnected. At bedding-scale the FU trends prevail over CU, and trough and tabular cross-bedding are common.

Megasequence B consists of en echelon-stacked, coarsely conglomeratic, FU concave-up units (Fig. 9c). Details at the bedding-scale are scarce but point to a higher proportion of $\mathrm{CU}$ conglomerates, which are also definitely coarser than those of the underlying megasequence.

Palaeocurrents of the Dromedary Conglomerate are oriented between west-southwest and northeast (Fig. 9f: average $330^{\circ}$ ).

Interpretation: The architecture of the coarse-clastic Dromedary Conglomerate (Fig. 9) is interpreted to result from alluvial fan depo- sition along the southern margin of the MC Basin. Grain size and grain size variation, and the mix of current and mass-flow transport indicated by the sedimentary structures, point to an alluvial fan environment for most of the megasequence A deposits. The CU at megasequence scale is explained by fan progradation. Progradation took place over an alluvial plain or fan fringe represented by the white cross-bedded in which the set of sedimentogical features is reminiscent of a desert-like environment with pebble pavements and flash flood deposits (cf. Rodriguez-Lopez et al., 2010). The low interconnectedness of the sandstone-conglomerate sheets in megasequence A points to a relatively high rate of subsidence. The stacked concave-up units of megasequence B, probably channel fills, represent a more proximal fan environment. The higher proportion of $\mathrm{CU}$ conglomerates indicates an increased influence of deposition by debris flows.

This change in sedimentary architecture from A to B took place during active tectonic deformation as witnessed by the abovementioned intraformational unconformity (Fig. 9c).

\subsubsection{The relationship of the southern margin sequence with the Au-mineralized zones}

To the south, the Cajuput Spring sandstone is juxtaposed with a chlorite-actinolite phyllite unit, about $250 \mathrm{~m}$ thick, that can be traced along the MSZ over at least $10 \mathrm{~km}$. Foliation is strike-parallel, with a steep north-westerly dip, and has been crenulated by a second vertical north-striking foliation, and shortened parallel to strike by conjugate kink-bands. Where the outcrop of the phyllite meets that of the Cajuput Spring sandstone (Fig. 8a/b) the latter also shows bedding-parallel fracturing with the same kink-bands, or is crushed into fault gouge.

To the NE, the MSZ links up with the Middle Creek mineralised zone that forms such a prominent feature in the MC block (Fig. 2). The strike of the sandstone beds and the axes of D3 folds also bend to the NNE (east of gridline 05 in Fig. 8a). Over several kilometres the sandstone forms the south-eastern limb of a major SW-plunging D3 syncline at the scale shown by the enveloping fold surface in the cross-section of Fig. 3. The white quartzose sandstone along the base of the Dromedary Conglomerate crops out in some of the smaller synclines within the major fold limb (grid block 08-72 in Fig. 8a).

Further eastwards, on the west bank of Five Mile Creek ${ }^{\mathrm{e}}$ (Fig. 2), talc schists and again chlorite phyllites prevail in the Middle Creek Au-bearing zone. Isolated synclinal keels of turbiditic sandstone show that the enveloping surface of these folds ascends southwards. Lenses of banded chert are encased in the shear zone.

Eastwards beyond Five Mile Creek at the Five Mile Mining Centre $^{\mathrm{f}}$, Dromedary Conglomerate and sandstone lie unconformably and with a jump in metamorphic grade on the chlorite phyllite (cf. Kisch and Nijman, 2010), while the Cajuput Spring sandstone is absent. This contact is correlated with the MC unconformity. The coarse Dromedary sediments here lie at the base of a ca. $400 \mathrm{~m}$ thick north-dipping sequence of MC sediments (Fig. 4, ref. 4a/b) composed of alluvial fan-delta platform (?) arenites, which grade upwards into shale with metres-thick proximal turbidites, and finally into the distal turbidites and basin shale of the Southern Blue Spec Syncline. Palaeocurrents in this turbidite sequence are due west.

Southward from the MSZ on the west bank of Five Mile Creek ${ }^{\mathrm{g}}$, the chlorite phyllite reappears in outcrop between various other rock types. The phyllite evidently follows the D3-fold pattern within the Kurrana Marginal Domain. 

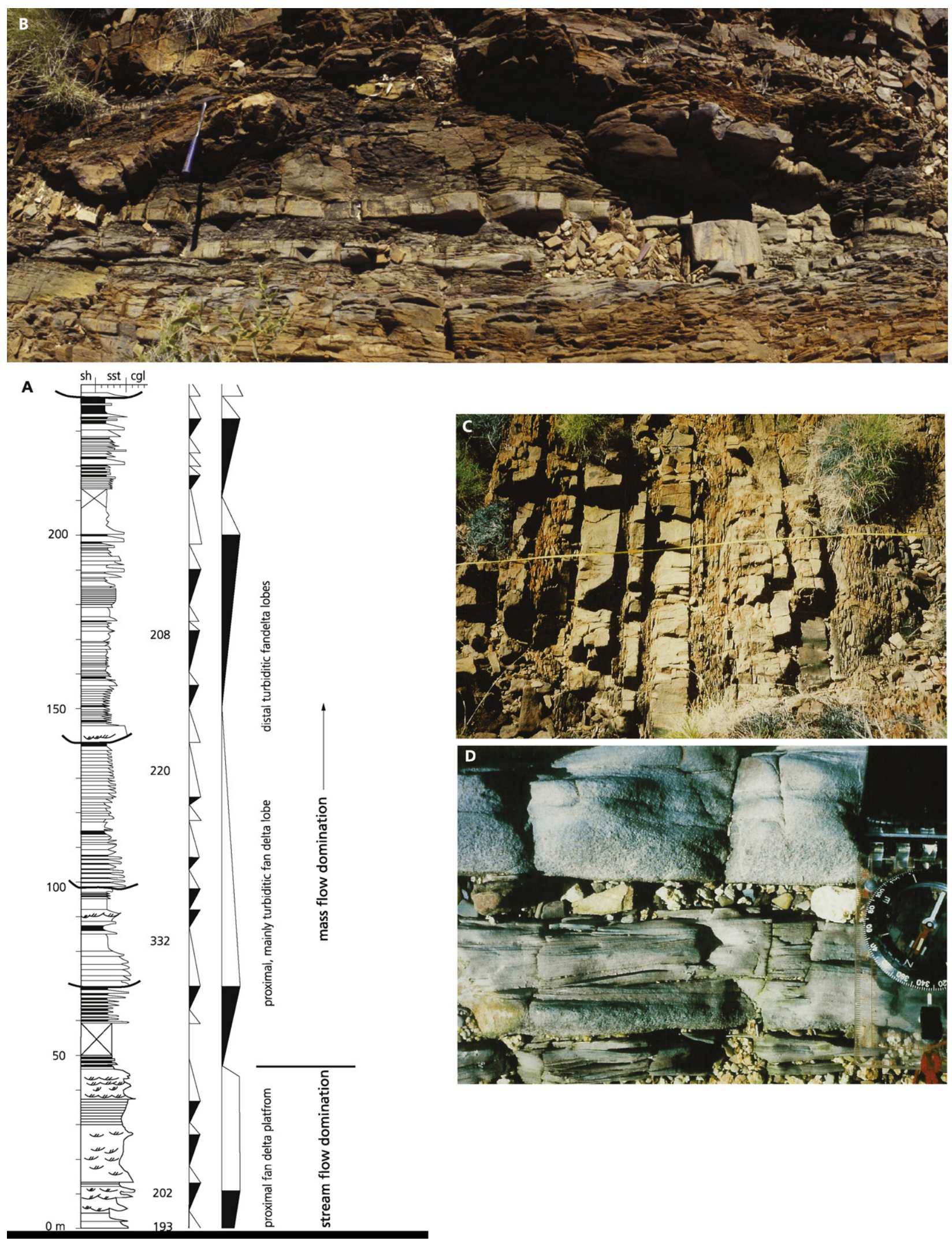

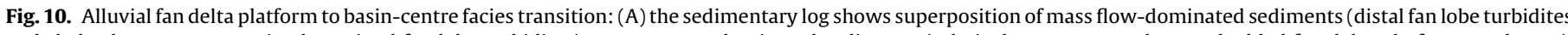

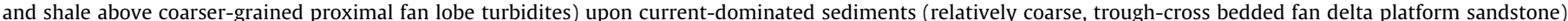

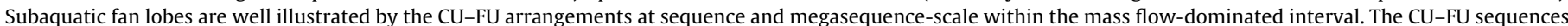

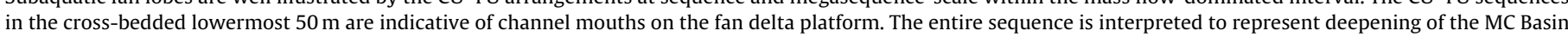

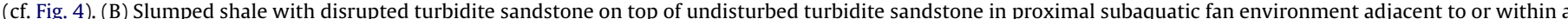

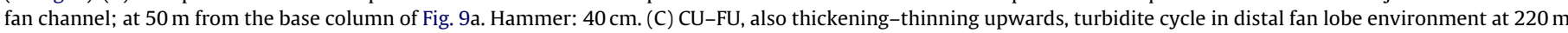

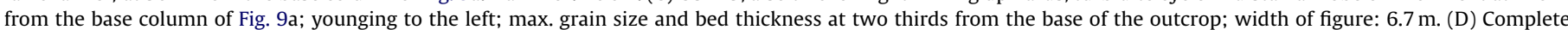

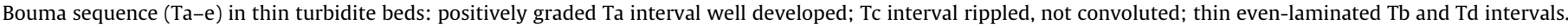
Scale on compass: $10 \mathrm{~cm}$. 


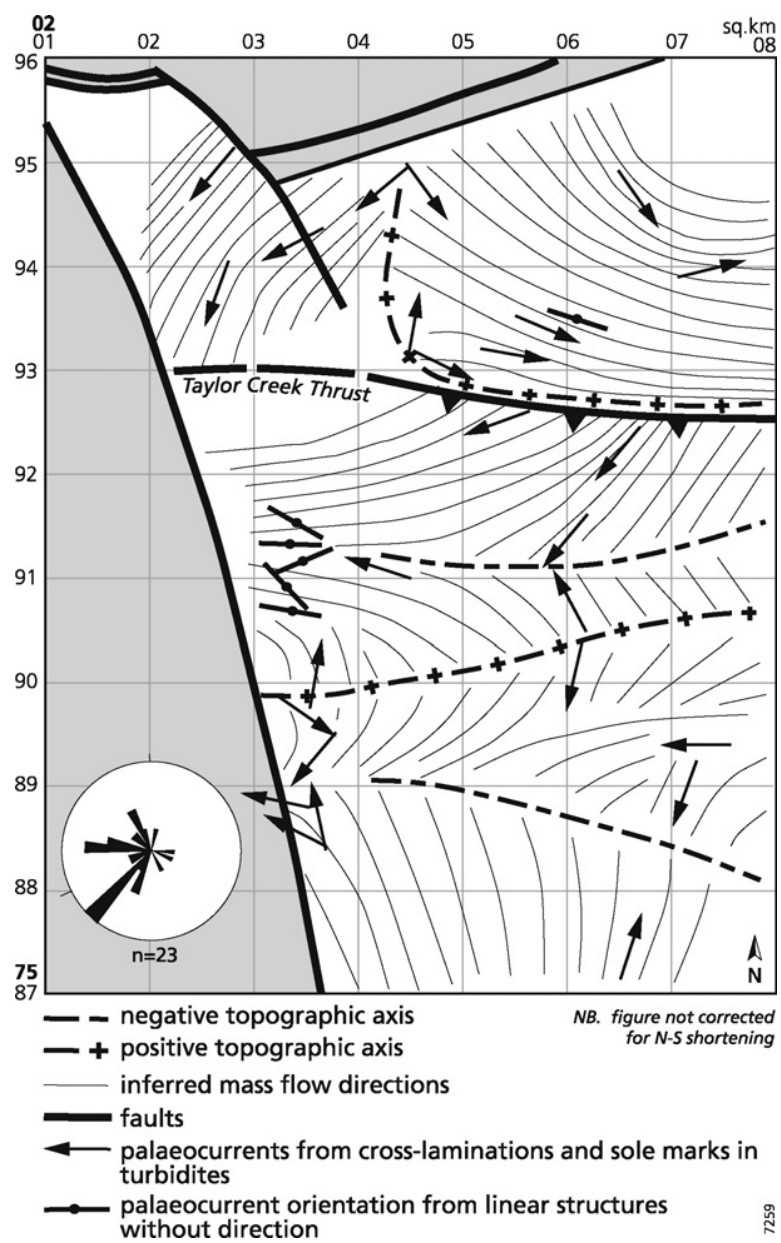

Fig. 11. Palaeocurrent distribution (map and rose iagram) in the NW segment of MC block, suggesting control on turbidity currents by sea bottom relief resembling the D3 fold pattern.

\subsection{The western boundary of the MC Basin: a late west-block down hinge}

The western boundary of the MC block consists of a southern and a northern segment, the first an unconformity, the second a fault (Fig. 2). The Fortescue unconformity truncates the tightly D3-folded MCFm. The youngest rocks of the MCFm below the unconformity are fluvial, white, quartzose sandstones identical to those exposed at Castle Hill (Fig. 4). They crop out below Tertiary terraces immediately NW of the village of Nullagine. In this area, the MCFm has relatively gentle westward dips of less than $50^{\circ}$. Structurally, the outcrops are situated in the central domain, along the western extension of the Northern Blue Spec Syncline and Blue Spec Anticline. Above the unconformity a moderately west-dipping sandstone-shale sequence correlates with the Hardey Formation, and includes the Glen Herring Shale (Fig. 4) and the Beatons Creek Conglomerate. All these formations belong to the Neoarchaean Fortescue Group.

The northern segment of the western block boundary is a fault that splays southwards into the MCFm. Splays and the main fault have a strong dextral horizontal component of displacement (interpretation based on horizontal offsets, tension gashes, Riedel faults and crenulation cleavage ${ }^{\mathrm{h}}$ ). The fault affects shale (Glen Herring Shale) and sandstone of the Hardey Formation and the underlying Mount Roe Basalt, and may be linked to the Lionel Lineament mentioned in the introduction (Fig. 1a).
A feldspar-porphyritic dyke bends from a vertical position along this boundary fault upwards into a subhorizontal sill (in places extrusive, Blake, 1993). It is known as the Bamboo Creek Member of the Hardey Formation in the lower part of the Fortescue Group (Fig. 4).

Interpretation: We follow the interpretation by Blake (1993), that the western boundary of the MC block is the expression of a west block-down flexure and growth-fault (his Conglomerate Creek Fault) becoming active at the end of the infilling of the MC Basin. This westward dipping flexure evidently generated unconformities in the sedimentary sequence it controlled along the western margin of the MC block, and was active over the Meso to Neoarchaean boundary. Its activity continued during deposition of the Fortescue Group whereby the flexure in the north developed into a west block-down dextral oblique fault, which became the pathway of the feldspar-porphyry intrusion. The western boundary fault therefore postdates the MCFm, the Fortescue unconformity and the basal part of the Fortescue Group, offsets the dolerite dykes (ca. $2772 \mathrm{Ma}$ ), and predates or is coeval with the emplacement of the Bamboo Creek porphyry sill (ca. $2766 \mathrm{Ma}$ ) (ages from Bagas et al., 2004b).

\subsection{The eastern boundary of the MC block}

The eastern block boundary has not been included in this study. The map of Farrell (2005) depicts the contact as an angular unconformity between the MCFm and the Fortescue Group, in places offset by NW-SE faults. In the gravity maps of Fig. 1b and $c$ the continuation of the basin towards the east below the Fortescue Group is not equivocal. The possible connections of the greenstone basement of the MC Basin with adjacent belts are indicated with arrows in Fig. 1b.

\section{The Mosquito Creek central basin facies}

In the previous section the northern, southern and western MC block boundaries have been identified as the margins of a sedimentary basin. Focus is now on the sedimentology of the central basin fill.

\subsection{The central basin fill sequence: proximal to distal submarine-fan facies}

Fig. 10 represents a sedimentary log from the Northern Chevron-folded Domain. It illustrates the FU transition from trough cross-bedded fan-delta platform sandstone via proximal into distal turbiditic submarine-fan facies. For details of the description we refer to Fig. 10.

Along the southern margin, the average palaeocurrent direction in the coarse-grained facies is to the NW (Fig. 9) with downstream deflections in the finer-grained facies both to the northeast, and to the west. Also along the northern margin (Fig. 11), southward transport is deflected to the east, while further to the south westward directions predominate. It should be noted that the amount of palaeocurrent measurements that could be measured reliably in these tightly folded Archaean sediments, is statistically insufficient. Nevertheless, when plotted on a map (Fig. 11), the paleocurrent directions produce a consistent pattern that appears to have been influenced by relief of the sea bottom reminiscent of the D3-fold geometry. corroborating the synsedimentary character of the deformation. The pattern further indicates axial drainage of the basin towards the west and southwest, with eastward counter-currents, and supports the interpretation of the facies transition from basin margin towards basin centre. 


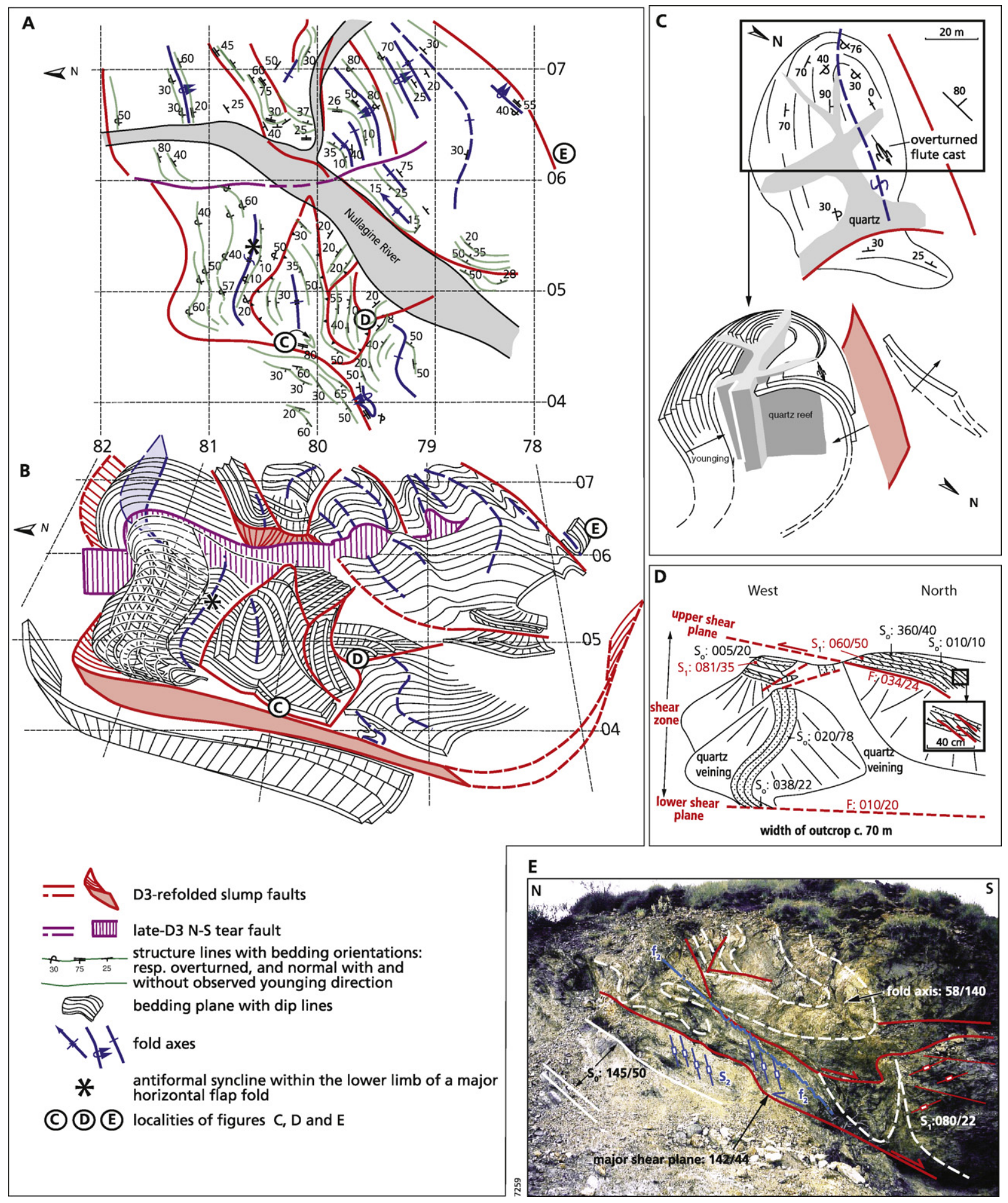

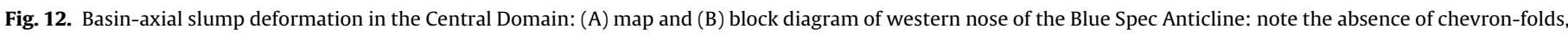

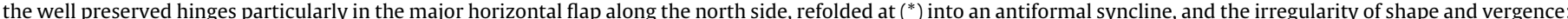

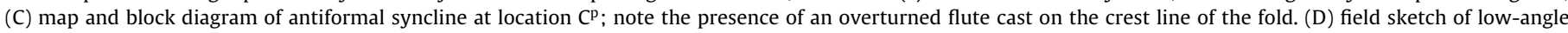

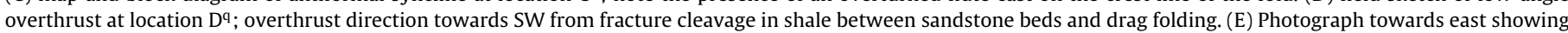

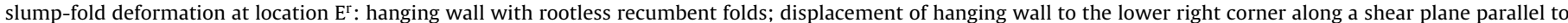

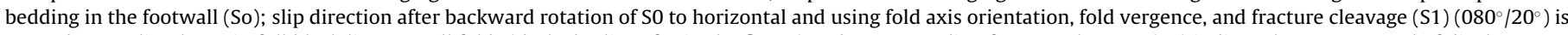

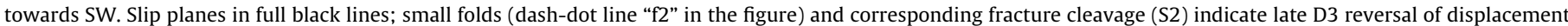
along major slump fault. 


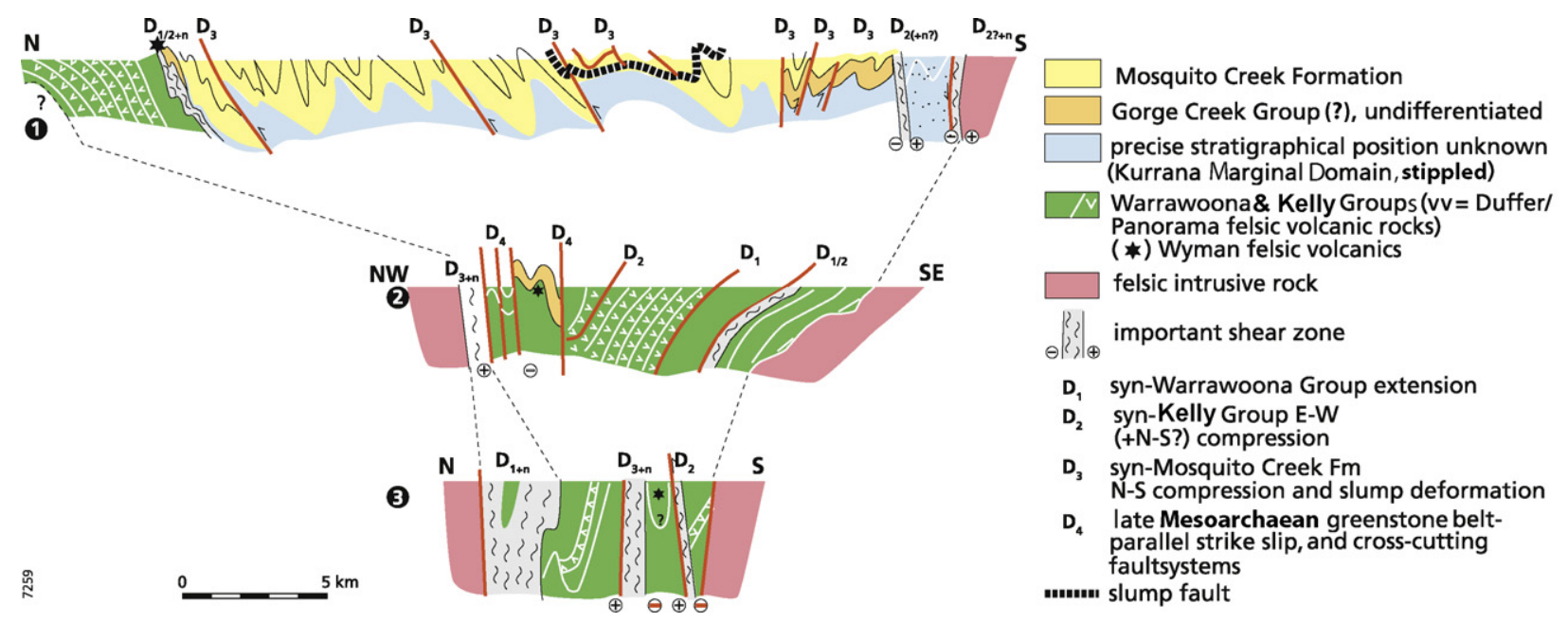

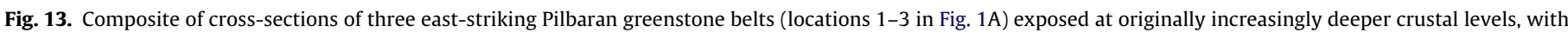

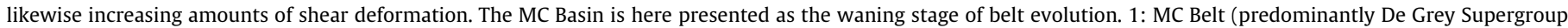

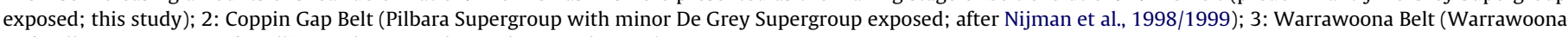
and Kelly Groups exposed; Collins et al., 1998; Kloppenburg et al., 2001).

\subsection{The central domain: a basin-axial slump}

Fig. 12 illustrates, in map view and 3D, the part of the Central Domain exposed along the traverse of Fig. 3. Notable differences with the general style of folding of the MCFm are:

(1) The overall low angle of bedding. Poles to the bedding cluster in the centre of the plot on a SW-dipping great circle (Fig. 3). The pole to the great circle is parallel to the average D3-fold axis in the western Mosquito Creek Block.

(2) Cleavages show a distribution similar to that of the bedding. This suggests they have a low-angle pre-D3 or early syn-D3 origin.

(3) The occurrence of inclined to overturned, often refolded, and sometimes rootless folds (Fig. 12a, b at * and Fig. 12c, e). The orientation of the refolded axial planes may deviate up to $90^{\circ}$ from the orientation of the main-phase folds.

(4) The occurrence of folded low-angle brittle shear zones. In the centre of the domain (Fig. 12d) displacement was NE over SW. Along the south side (Fig. 12e) overturned folds show the same orientation on a $140 / 58$ dipping fault.

(5) Bedding-parallel slip planes are found with chlorite-coated slickensides plunging north and south.

From the observations (1) to (4) it is concluded that many of the folds and the folded low-angle shear zones have been formed before the main phase of $\mathrm{N}-\mathrm{S}$ shortening. Since at least the onset of that shortening is coeval with sedimentation (see Sections 3.2.1 and 2 ), it follows that the low-angle deformation with NE over SW displacements, is synsedimentary as well. The combination of turbidites with inclined to overturned, sometimes rootless folds with complete, rounded hinges then immediately points to an origin of slopedown gravitional collapse, i.e. due to slumping. The slip direction is roughly parallel to the basin axis and to the pattern of westward palaeocurrent deflection. The slump unit is horseshoe-shaped and situated in the North and South Blue Spec Synclines and along the WSW-plunging nose of the Blue Spec Anticline. This also suggests that the Blue Spec folds were already present as active growth structures enhancing primordial slope failure (compare Fig. 14).

Variation in clay mineral composition due to differential burial metamorphism also suggests an early growth of the Blue Spec Anticline (Kisch and Nijman, 2010).
The occurrence of chlorite-plastered slip planes with N-S slickensides is interpreted to be due to flexural-slip during subsequent main-phase compressive deformation under the then increased sedimentary load.

\section{The Mosquito Creek basin, synthesis and discussion}

\subsection{The northern and southern basin margins compared}

\subsubsection{Cajuput Spring sandstone and Cooke Creek unit}

Because of the pinchout of the Cajuput Spring sandstone to the east and of the Cooke Creek unit to the west, and because of their unconformable lower and upper contacts and stratigraphical position below the bulk of the MC Basin fill, these units are here considered not to belong to the MCFm proper (Fig. 4). A correlation between the two units seems obvious but the amount of outcrop is insufficient for further interpretation of the facies distribution. It is interesting to note that in the provenance study of Bagas et al. (2008) the 4 samples taken from sandstones below the McPhee Creek conglomerate, and therefore probably from the Cooke Creek unit, show a different source composition (EPT) than the samples from the turbiditic basin-centre facies of the MCFm (sensu stricto), for which a source area in the east Hamersley Basin or the southern Kurrana Terrane is proposed. The eight sample locations discussed in their paper are however too clustered in two particular domains of the MC Basin to allow firm conclusions about the provenance of the basin fill as a whole.

\subsubsection{Dromedary and McPhee Creek conglomerates of the Mosquito Creek Formation}

The combination of data from the Dromedary Hills and from the composite basin fill sequence in the Central Domain (Fig. 4) results in a general picture of the geometry of the Dromedary Conglomerate along the southern basin margin. At the very margin, in the Dromedary Hills, the two megasequences (A and B) of the Dromedary Conglomerate show one overall CU trend, due to alluvial fan progradation. Megasequence A correlates with the basal half of the basin fill sequence in the central domain, and is interpreted to have formed during relatively strong subsidence. Along the basin margin this prevented pronounced basinward progradation of the alluvial fan, and caused the stacking of conglomerate sheets and the formation of a subsiding fan-delta platform in its 


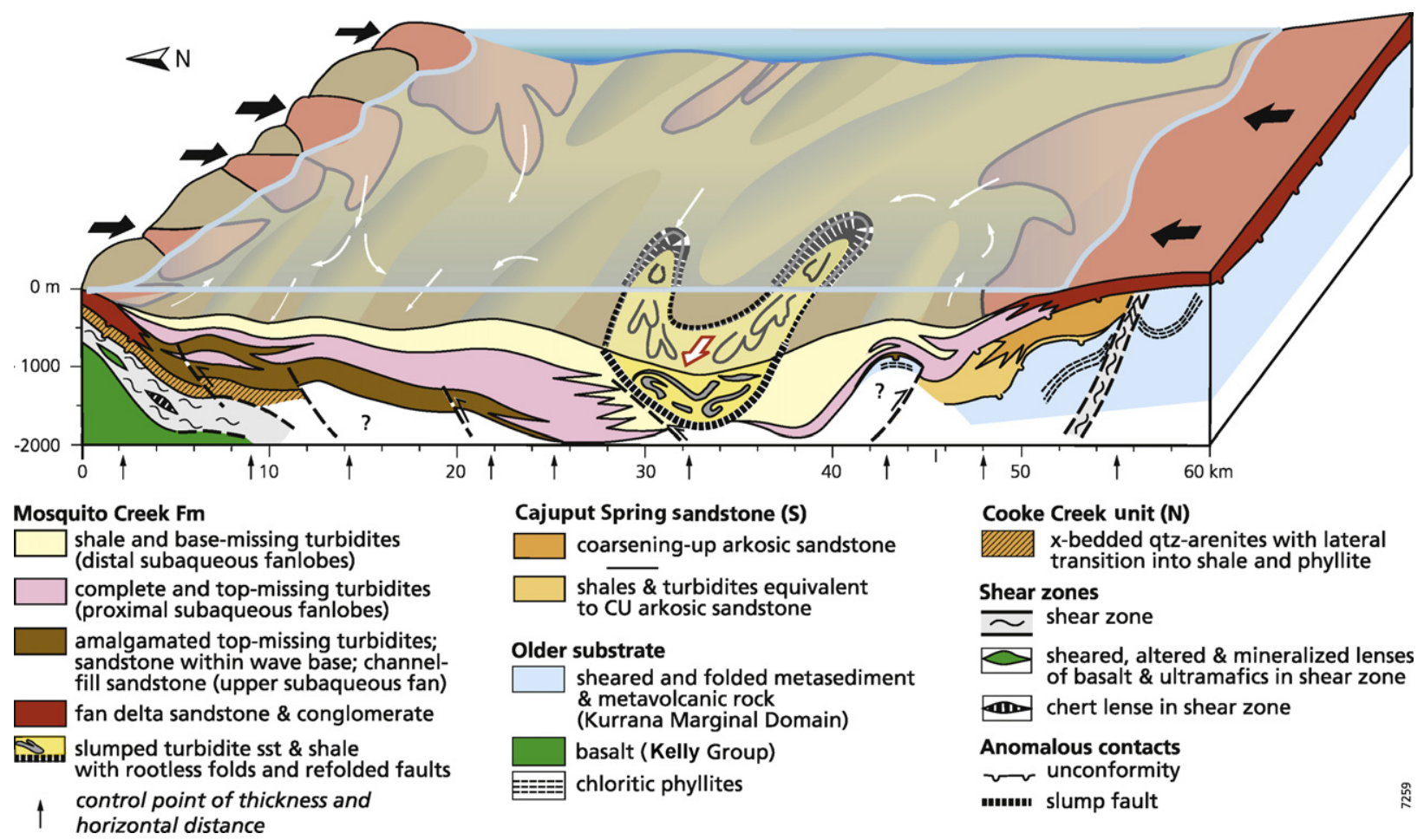

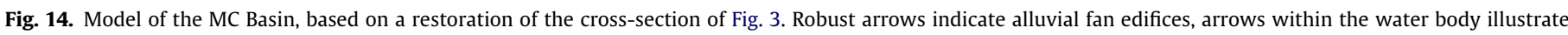

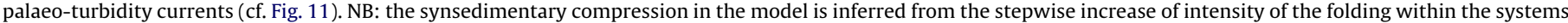
of stacked marginal unconformities, in particular along the south side (cf. Fig. 8B).

front. During maximum subsidence, slope instability generated slumping in the central domain. Along the southern margin an intraformational unconformity was formed.

The MC unconformity at the base of the Dromedary Conglomerate is here correlated with the unconformity below the McPhee Creek conglomerate in the north (Fig. 4). The overlying CU Dromedary Conglomerate, in particular megasequence $\mathrm{A}$, is in outcrop continuity with the FU basin-fill sequence of the central domain, for which in the north the McPhee Creek conglomerate forms the base. The argument for the north-south correlation is therefore the geometrical relationship rather than the $\mathrm{CU}$ or FU trends in the basin-margin conglomerates. Grain size trends (Figs. 7 and 9) are not reliable correlation tools since they depend on slope gradient and basin-margin behaviour that were probably different in the south and north, and possibly even between adjacent fans.

Tentatively, we compare the white sandstones in the top of the MC Formation near the village of Nullagine (cf. Section 3.3), with the quartzose sandstone facies at the base of the Dromedary Conglomerate. If so, and considered its position above the turbidites and slump deposits of the Central Domain, these sandstone near Nullagine would then represent the regressive top of the basin fill (Fig. 4).

The relationship between folding, faulting and stacking patterns of the marginal unconformities proves that the D3-folding must have started already before the deposition of the basal units of the MCFm such as the lower part of the Dromedary Conglomerate in the south (cf. Fig. 8b, cross-section 3). Deposition of the MCFm postdated much of the deformation in the NSZ and MSZ.

\subsection{The Mosquito Creek Basin: an underfilled basin}

The pronounced FU trend from alluvial fan(-deltaic) conglomerate to very shaly turbidites resembles the response to the rapid subsidence characteristically found in fault-controlled, extensional basins (cf. the interpretation of Bagas et al., 2008). The first pulse of subsidence controls the building of alluvial fan(delta)s along the margins, shelf sandstone and proximal turbidite fans away from the margins, distal turbidites and shale in the centre of the basin. The fact that the flanking fans consist predominantly of massive and megacross-bedded framework conglomerate and sandstone precludes their origin as high-density mass-flow conglomerates in a sub-aqueous fan environment.

With increase of the ratio between subsidence and sedimentary infilling, the basin becomes more and more underfilled. Coarse-clastic facies tend to give way to top-missing, subsequently base-missing turbidites, followed by shale. Paradoxically, the situation of underfill was accompanied by compressive folding. In most compressional basins, like foreland and forearc basins, the developing hinterland relief accounts for sufficient clastic supply to keep pace with the high rate of subsidence, which leads to overfill of the basin (cf. Section 5).

It is not necessary to consider the MC Basin as a marine environment because of an interpretation of the turbidite deposits as submarine-fan facies. The basin was only $60 \mathrm{~km}$-wide and was rimmed by alluvial deposits. The only statement that can be made for the remainder of the basin fill is that it was subaquatic and, because of mass-flow dominance in the central basin facies, was generated along relative high gradients. It is more likely to have been situated in an intracontinental, or intramontane setting, such as an uplifted GGT with differential vertical movements. As to the latter aspect of vertical tectonics this interpretation matches the one proposed by Hickman (1984).

\subsection{Comparison with other Pilbaran greenstone belts}

In Fig. 13 the cross-section of the MC block of Fig. 3 is compared with those of two other nearby east-striking greenstone belts of the EPT, the Warrawoona and Coppin Gap belts (Fig. 1a for locations). 
All sections contain folded and non-folded shear zones and sheared contacts on one or the other side with the granitic basement. There is no fundamental difference in the style of deformation of the three belts, other than their decreasing PT-conditions from cross-sections 1 to 3 . Superposition of the cross-sections as depicted, therefore produces a reliable and almost complete 2D cross-section of an East Pilbaran greenstone belt. This better agrees with Blewett's (2002) interpretation of the MC block as the aftermath of a greenstone belt within the EPT, than as a feature related to a terrane boundary or as a separate terrane (cf. Section 1.1.1).

Finally, the stacking of unconformable contacts between the NSZ and the De Grey Supergroup along the northern MC Basin boundary, compares with the situation in the Bamboo Creek Syncline of the Coppin Gap Belt, $90 \mathrm{~km}$ to the north (Fig. 1a). In the latter, the Bamboo Creek Shear Zone (BCSZ) is situated not far below two overlying De Grey Supergroup clastic sediment suites (Farrell Quartzite and conglomerate of the Cundalina Formation, Williams, 1999; respectively, clastic units I and II in Nijman et al., 1998/1999). The NSZ and BCSZ share the same mineralogy, sense of displacement, and an original bedding-parallel attitude, and show only a slight difference in dating (youngest rocks involved of $3292 \mathrm{Ma}$ in the NSZ and $3315 \mathrm{Ma}$ in the BCSZ) (Nijman et al., 1998/1999; Williams, 1999; Zegers et al., 2002; De Vries et al., 2006). This correspondance may support a right-lateral displacement along a major feature like the proposed Lionel Lineament. On the other hand, it should be reminded that in the geophysical maps of the east Pilbara (Blewett et al., 2000) no fundamental basement fault has been recognised in the position of the Lionel Lineament.

\subsection{Comparison with other Archaean siliciclastic basins}

Sediments of comparable age and composition to those found in the MC Basin have been recorded from other parts of the Pilbara. The Lalla Rookh Basin (Krapez and Barley, 1987; Van Kranendonk et al., 2007) of the East Pilbara is mainly filled by coarse-grained arkosic sandstones in a strike-slip setting related to one of the major N-S shear zones within the EPT (Fig. 1a). The Mallina Basin of the West Pilbara has many aspects in common with the MC Basin (see below). Other similar clastic basins are known from the Kaapvaal Province of South Africa, and the Superior Province, Canada.

In the Barberton Greenstone Belt the (ultra)mafic rock suite of the Upper Onverwacht Group (>3.28 Ga; ages for the Barberton Greenstone Belt in this paragraph after Lowe and Byerly, 1999) is overlain by the Fig Tree Group (3.26-3.22 Ga). The Fig Tree Group is essentially a CU sequence (Mapepe Fm; Lowe and Nocita, 1999) from fine-grained pyroclastic suspension-settled deposits grading via turbidites into sub-aqueous fan-delta deposits and braided alluvial sediments. The Fig Tree Group is overlain by the conglomeratic to sandy Moodies Group with a FU trend (3.22-3.10 Ga) (Heubeck and Lowe, 1994). The overall CU/FU-trend at the scale of a succession of basins is interpreted to result from cratonisation and fold-and-thrust belt tectonics (cf. Jackson and Eriksson, 1987; Eriksson et al., 1994; Heubeck and Lowe, 1999).

Compressional settings in convergent plate margins generally result either in a structurally strongly asymmetrical succession from a turbiditic forearc basin fill into a tectonic melange, or in a likewise asymmetrical, but CU foreland basin fill from turbidite facies into voluminous alluvial fans like in the classical molasse basins (cf. interpretation of the clastic Cheshire Formation in the Belingwe Greenstone Belt by Hofmann et al., 2001, and the Beardmore-Geraldton terrane of the Canadian Superior Province by Barrett and Frålick, 1989; Frålick, 1992; Eriksson et al., 1994).

The MC Basin fill is fundamentally different because the basin fill sequence is FU instead of CU. This is also the case with the Mallina
Basin in the West Pilbara. The 2970-2955 Ma old sequence of the subarkosic Constantine Sandstone into the overlying shale and finegrained wacke of the Mallina Formation has been interpreted as a submarine-fan environment in an extensional intracontinental setting (Smithies et al., 2001; cf. also Pike and Cas, 2002). Likewise, the $2.65 \mathrm{Ga}$ old clastic sediments of the Bindura-Shamva Greenstone Belt in Zimbabwe form a FU sequence from alluvial conglomerate into turbidites (continental extension), which is then however followed by a CU sequence (foreland or fore-arc basin compression) (Hofmann et al., 2002).

Modern analogues with similar facies associations and basin evolution are fault-bounded rift basins, back-arc basins or small intramontane basins. They are characterized by fan-deltas along the margins and an overall FU turbiditic basin fill (cf. McDonald, 1986). These extensional or transtensional basins in tectonically active settings are known for the high subsidence rates in proportion to the sediment input. The underfill of the MC Basin is therefore neither a common nor an exceptional feature. What is indeed exceptional, also in comparison with modern analogues, is that the basin shows the grainsize trend of an extensional basin, but the structural development of a compressional basin (Fig. 14). The symmetrical facies arrangement from northern to southern margin and the fanning of axial planes along the basinal cross-section does not point to a unidirectional compressive translation as in foreland and fore-arc basins. Rather it conforms to a basin with equally active margins along hinges between uplift areas and the subsiding basin.

Compressive deformation took place under conditions of net subsidence. The resulting deepening of the basin, with short and steep marginal gradients, combined with synsedimentary compressive folding with outward verging folds resembles the setting of the squeezed rim synclines of diapirs of Dixon and Summers (1983; cf. Korsch, 1982). Compressive deformation in the form of a fan of folds combined with the southward deflection of the basin axis in the west and the crescent subcrop shape of the basin could also be the result of a transpressive push-up or positive flower structure. This argument is strengthened by the fact that the tight main-phase folding is restricted to the basin-or even only to the MC block - itself. In such a setting, the NSZ would also have functioned as a left-lateral double-bend strike-slip fault delimiting the basin. This, however, presupposes a preceding negative, i.e. extensional or transtensional (pull-apart) basin forming process. The D3 folding of the NSZ (cf. Section 3.1.1) precludes such a synsedimentary strike-slip mechanism for that fault zone and also explains the observed reversal of the sense of strike-slip.

Net basin subsidence under compression is well explained by isostatic sinking, and consequently squeezing, of the greenstone succession between rising positive structures (cf. for reviews on diapiric effects and vertical tectonism in Pilbaran greenstone belts: Hickman, 1984, 2004; Van Kranendonk et al., 2004, 2007). We consider this process responsible for turning an already deformed greenstone succession into a greenstone "belt" in the original sense of the dome-and-belt architecture of the Pilbara Craton. In general, such positive structures in the Pilbara are granitoid batholiths, but they can be almost devoid of voluminous granite bodies like the North Pole and McPhee Domes. The Mc Phee Dome is here explained as a product of interference of the belt-forming processes in the surrounding four greenstone belts (see Section 1.1.1).

In our opinion vertical crustal movements only controlled the belt-forming phase (D3) of GGT development (cf. Blewett, 2002). Preceding (pre-D3) deformations were namely characterized by the formation of low-angle detachments (i.e. shear zones) under quite different extensional and compressional regimes unrelated to the dome-and-belt structure as it now appears in the Pilbara Craton (Zegers et al., 1996; Blewett, 2002; Nijman and De Vries, 2004; De Vries et al., 2006). The formation of the MC Basin represents the last, or waning stage of the belt-forming process. 


\section{Conclusions: the Mosquito Creek Basin, the waning stage of a greenstone belt}

(1) Two clastic suites can be distinguished in the MC block. The older suite (Cooke Creek unit in the north, and Cajuput Spring sandstone in the south) has been preserved fragmentarily, which makes correlation between the units uncertain. This older suite is not identical with the Coondamar Formation, recently distinguished by Bagas (2005) and Farrell (2006), but rather belongs together with the latter to a heterogenous, folded, tectono-stratigraphical unit, such as represented by the Kurrana Marginal Domain. The upper clastic suite, that overlies this unit with a jump in metamorphic grade, is here considered to be the MCFm proper.

(2) The MCFm is the fill of a sedimentary basin (Fig. 14) of which the northern, southern and western boundaries coincide with the MC block as a structural unit. Coarse-clastic fandeltaic marginal facies occur along the northern (McPhee Creek conglomerate) and southern boundaries (Dromedary Conglomerate). Progressive unconformities truncate fold structures and so witness the structural control by synsedimentary N-S compression.

(3) The basin-centre facies of the MCFm consists of one major FU sequence from fan-delta conglomerate and sandstone into distal turbidites, and contains a large chaotic slump unit with rootless folds situated in the basin axis. This deepening sequence indicates a higher rate of subsidence than of sedimentation, with the concurrent effect of slope instability.

(4) Within the MCFm, palaeocurrents converge from northern and southern source areas towards the basin centre where they bend predominantly to the west, though in places also to the east. In detail, the palaeocurrent distribution appears to have been influenced by local (growth fold?) relief of the sea bottom.

(5) Because of conclusions 2-4, the MC Basin is an underfilled, compressional, intramontane, clastic sedimentary basin. It is superposed with marginal unconformities on a volcanic greenstone belt rock assemblage with enclosed shear zones. Vestiges of an earlier unconformable clastic sequence (the Cajuput Spring sandstone and Cooke Creek unit: the Gorge Creek Group phase of clastic sedimentation?) have been preserved locally between the volcanic substrate and the MCFm. The preunconformity deformation of this substrate was not related to the dome-and-basin structure that controlled the architecture of the MC Basin. Comparison with adjacent belts allows the conclusion that the MC Basin represents the waning stage of a greenstone belt within the EPT, during which vertical crustal displacements prevailed due to doming primarily of granitoid bodies, and rarely - as a derivative of the latter - of a greenstone complex like the McPhee Dome. Between the domes, greenstone belts actively subsided, a process emphasized by sedimentary loading. The reaction to the space problem created by subsidence between rising domes was compressive deformation resulting in a synclinorial style of tight folding with fanning axial planes. This occurred under conditions of net subsidence, a setting probably not having many analogues other than the rim synclines between salt diapirs.

(6) Termination of the basin development and therefore of the greenstone belt as a whole is indicated by the stage of maximum alluvial fan progradation of Dromedary Conglomerate B along the southern margin and by a very locally preserved, alluvial facies on top of the central basin fill near Nullagine. This may indicate isostatic rebound of the block after initial sagging between rising domes. A NNE-SSW tectonic hinge (probably related to the Lionel Lineament) developed at high angles to the belt axis along which coarse-clastic sediments, stacked unconformities, and second-order dextral $\mathrm{N}-\mathrm{S}$ faults became concentrated. This heralded the completely new basin configuration of the Mount Bruce Supergroup during the Neoarchaean.

\section{Acknowledgements}

First results of this study have been presented at the 16th International Association of Sedimentologists Conference at Johannesburg in 2002 (Abstract vol. 2002, p. 280). The study forms part of the Early Earth Sedimentary Basins (EEB) project supported by the Dutch Dr. Schürmannfonds with grants nrs. 1996/14, 1997/14, 1998/14, 2000/14, 2002/10, 2005/32. We gratefully acknowledge the comments of Prof Poppe de Boer and the review by Dr Axel Hoffman. We are much indebted to Dr Richard Blewett for his review, in particular for discussing the deeper structure and a possible strike-slip character of the basin. Dr. Jan Wijbrans (Free University, Amsterdam) carried out the dating on the rhyolite at Curtin University, Perth, W.A. Mrs Margriet Ganzeveld of Geomedia at Utrecht University prepared the figures.

\section{Appendix 1. Locations mentioned in text and figure captions} $51 \mathrm{~K}$

$N B$. The GPS notations refer to the Australian Map grid, Zone

a MGA 212997E/7598756N

b MGA 219653E/7598835N;

c MGA 235510E/7600815N;

d MGA 203200E/7569400N:

e Between MGA 209400E/7572840N and 209610N/7571820E;

${ }^{\mathrm{f}} \mathrm{MGA} 211600 \mathrm{E} / 7573400 \mathrm{~N}$;

g MGA 210630E/7569230N;

${ }^{\mathrm{h}}$ For example MGA 203634E/7588734N;

i Between MGA 213567E/7576009N and 213594E/7576567N;

j MGA 203825E/7591300N;

k MGA 215500E/7598500N;

${ }^{1}$ MGA 214804E/7598877N;

m MGA 205350E/7595433N

${ }^{n}$ MGA 203925E/7569525N;

o MGA 206000E/7591300N;

p MGA 204495E/757970N;

${ }^{q}$ MGA 204789E/7579524N

${ }^{r}$ MGA 206240E/7577629N.

\section{References}

Bagas, L., 2005. Geology of the Nullagine 1:100 000 sheet. Western Australia Geological Survey, 1:100 000 Geological Series Explanatory Notes, 33 pp.

Bagas, L., Beukenhorst, O., Hos, K., 2004a. Nullagine, W.A. Sheet 2954. Western Australia Geological Survey, 1:100 000 Geological Series.

Bagas, L., Farrell, T.R., Nelson, D.R., 2004b. The age and provenance of the Mosquito Creek Formation. Western Australia Geological Survey. Annual Review 2003-2004, 62-70.

Bagas, L., Bierlein, F.P., Bodorkos, S., Nelson, D.R., 2008. Tectonic setting, evolution and orogenic gold potential of the late Mesoarchaean Mosquito Creek Basin, North Pilbara Craton, Western Australia. Precambrian Res. 160, 237-244.

Barley, M.E., Pickard, A.L., 1999. An extensive, crustally-derived, 3325 to 3310 Ma silicic volcanoplutonic suite in the eastern Pilbara Craton: evidence from the Kelly Belt, McPhee Dome and Corunna Downs Batholith. Precambrian Res. 96, 41-62.

Barley, M.E., Loader, S.E., McNaughton, N.J., 1998. 3430 to 3417 Ma calc-alkaline volcanism in the McPhee Dome and Kelly Belt, and growth of the eastern Pilbara Craton. Precambrian Res. 88, 3-23.

Barrett, T.J., Frålick, P.W., 1989. Turbidites and iron formations, Beardmore-Geraldton. Ontario: application of a combined ramp-fan model to Archean clastic and chemical sedimentation. Sedimentology 36, 221-234.

Blake, T.S., 1987. A report on exploration activities on prospecting licenses P46/169172: South Dromedary ridge, Nullagine, Western Australia. Unpubl. Rep. Taurus resources N.L., 27 pp. + app.

Blake, T.S., 1993. Late Archean crustal extension, sedimentary basin formation, flood basalt volcanism and continental rifting: The Nullagine and Mount Jope Supersequences, Western Australia. Precambrian Res. 60, 185-241.

Blake, T.S., Buick, R., Brown, S.J.A., Barley, M.E., 2004. Geochronology of a late Archaean flood basalt province in the Pilbara Craton. Australia: constraints on basin evolution, volcanic and sedimentary accumulation, and continental drift rates. Precambrian Res. 133, 143-173. 
Blewett, R.S., 2002. Archaean tectonic processes: a case for horizontal shortening in the North Pilbara Granite-Greenstone Terrane, Western Australia. Precambrian Res. 113, 87-120.

Blewett, R.S., Wellman, P., Ratajkoski, M., Huston, D.L., 2000. Atlas of North Pilbara Geology 1:1.5 Million Scale, Aust. Geol. Surv. Org., Rec. 2000/4.

Blewett, R.S., Huston, D.L., Mernagh, T.P., Kamprad, J., 2002. The diverse structure of Archaean lode gold deposits of the southwest Mosquito Creek belt, east Pilbara craton, Western Australia. Econ. Geol. 97, 787-800.

Blewett, R.S., Shevchenko, S., Bell, B., 2004. The North Pole Dome; a non-diapiric dome in the Archaean Pilbara Craton, Western Australia. Precambrian Res. 133, $105-120$.

Collins, W.J., Van Kranendonk, M.J., Teysier, C., 1998. Partial convective overturn of Archaean crust in the east Pilbara Craton, Western Australia: driving mechanisms and tectonic implications. J. Struct. Geol. 20, 1405-1424.

De Vries, S.T., Nijman, W., Wijbrans, J.R., Nelson, D.R., 2006. Stratigraphical continuity and early deformation of the central part of the Coppin Gap Greenstone Belt, Pilbara, Western Australia. Precambrian Res. 147, 1-27.

De Wit, M., Ashwal, L.D., 1997. Greenstone Belts. Oxford Monographs on Geology and Geophysics. Clarendon Press, Oxford, 35, xxvii + 809 pp.

Dixon, J.M., Summers, J.M., 1983. Patterns of total and incremental strain in subsiding troughs: experimental centrifuged models of inter-diapir synclines. Can. J. Earth Sci. 20, 1843-1861.

Eriksson, K.A., 1981. Archaean platform-to-trough sedimentation, east Pilbara Block, Australia. In: Glover, J.E., Groves, D.I. (Eds.), Archaean Geology. Geol. Soc. Aust., Spec. Publ., 7, pp. 235-244.

Eriksson, K.A., Krapez, B., Frålick, P.W., 1994. Sedimentology of Archean greenstone belts: signatures of tectonic evolution. Earth-Sci. Rev. 37, 1-88.

Farrell, T.R., 2005. Eastern Creek, W.A. Sheet 3054 (2nd version). Western Australia Geological Survey, 1:100 000 Geological Series.

Farrell, T.R., 2006. Geology of the Eastern Creek 1:100000 sheet. Western Australia Geological Survey, 1:100 000 Geological Series Explanatory Notes, 33 pp.

Ferguson, K.M., Ruddock, I., 2001. Mineral Occurrences and Exploration Potential of the East Pilbara. Geological Survey of Western Australia. Report 81, 114 pp.

Frålick, P.W., 1992. Trench and slope basin deposits in an Archean metasedimentary belt, Superior Province Canada. Can. J. Earth Sci. 29, 2552-2557.

Heubeck, C., Lowe, D.R., 1994. Depositional and tectonic setting of the Archean Moodies Group, Barberton Greenstone Belt, South Africa. Precambrian Res. 68, 257-290.

Heubeck, C, Lowe, D.R., 1999. Sedimentary petrography and provenance of the Archean Moodies Group, Barberton Greenstone Belt. In: Lowe, D.R., Byerly, G.R. (Eds.), Geologic Evolution of the Barberton Greenstone Belt, South Africa. Geol. Soc. Am. Spec. Pap. 329, pp. 259-286.

Hickman, A.H., 1975. Precambrian structural geology of part of the Pilbara region. W. Aust. Geol. Surv. Annu. Report 1974, pp. 86-73.

Hickman, A.H., 1978. Explanatory Notes on the Nullagine Geological Sheet, 1:250.000 geological series, sheet SF 51-5. Geological Survey of Western Australia, Perth, Western Australia, 22 pp.

Hickman, A.H., 1983. Geology of the Pilbara Block and its environs. W. Aust. Geol. Surv., Bull. 127, 268 pp.

Hickman, A.H., 1984. Archaean diapirism in the Pilbara Block, Western Australia. In: Kröner, A., Greiling, R. (Eds.), Precambrian Tectonics Illustrated. Schweizerbart'sche Verlagsbuchhandlung, Stuttgart, Germany, pp. 113-127.

Hickman, A.H., 2004. Two contrasting granite-greenstone terranes in the Pilbara Craton, Australia: evidence for vertical and horizontal tectonic regimes prior to 2900 Ma. Precambrian Res. 131, 153-172.

Hofmann, A., Dirks, P.H.G.M., Jelsma, H.A., 2001. Late Archaean foreland basin deposits, Belingwe greenstone belt, Zimbabwe. Sediment. Geol. 141/142, 131-168.

Hofmann, A., Dirks, P.H.G.M., Jelsma, H.A., 2002. Late Archaean clastic sedimentary rocks (Shamvaian Group) of the Zimbabwe craton: first observations from the Bindura-Shamva greenstone belt. Can. J. Earth Sci. 39, 1689-1708.

Huston, D., Blewett, D., Baker, R., Smithies, H., 1999. The diverse origin of Archaean lode gold in the North Pilbara. Western Australia: a field excursion. AGSO Canberra, $40 \mathrm{pp}$.

Huston, D., Sun, S.-S., Blewett, R., Hickman, A.H., Van Kranendonk, M., Phillips, D., Baker, D., Brauhart, C., 2002. The timing of mineralization in the Archaean North Pilbara terrain, Western Australia. Econ. Geol. 97, 733-755.

Jackson, M.P.A., Eriksson, K.A., 1987. Early Archean foredeep sedimentation related to crustal shortening: a reinterpretation of the Barberton sequence, southern Africa. Tectonophysics 136, 197-221.

Kisch, H.J., Nijman, W., 2010. Metamorphic grade and gradient from white K-micas of Na-mica bearing sedimentary rocks in the Mosquito Creek Basin, East Pilbara Craton, W. Australia. Precambrian Res. 176, 11-26.

Kloppenburg, A., White, S.H., Zegers, T.E., 2001. Structural evolution of the Warrawoona Greenstone Belt and adjoining granitoid complexes, Pilbara Craton, Australia: implications for Archaean tectonic processes. Precambrian Res. 112, 107-147.

Korsch, R.J., 1982. The Dummy Creek Association: Rim Syncline Deposits. J. Proc. R. Soc. New South Wales 115, 13-19.

Krapez, B., 1984. Sedimentation in a small, fault-bounded basin: the Lalla Rookh sandstone, east Pilbara Block. In: Muhling, J.R., Groves, D.I., Blake, T.S. (Eds.), Archaean and Proterozoic Basins of the Pilbara, Western Australia: Evolution and
Mineralization Potential. University of Western Australia, Geology Department and University Extension, Publication 9, 89-110.

Krapez, B., Barley, M.E., 1987. Archaean strike-slip faulting and related ensialic basins: evidence from the Pilbara Block, Western Australia. Geol. Mag. 124, 555-567.

Lipple, S.L., 1975. Definitions of new and revised stratigraphic units of the eastern Pilbara Region, West Australia Geol. Survey Ann. Rept. 1974, 58-63.

Lowe, D.R., Byerly, G.R., 1999. Stratigraphy of the west-central part of the Barberton Greenstone Belt, South Africa. In: Lowe, D.R., Byerly, G.R. (Eds.), Geologic Evolution of the Barberton Greenstone Belt, South Africa. Geol. Soc.Am. Spec. Pap. 329, pp. 1-36.

Lowe, D.R., Nocita, B.W., 1999. Foreland basin sedimentation in the Mapepe Formation, southern facies Fig Tree Group. In: Lowe, D.R., Byerly, G.R. (Eds.), Geologic Evolution of the Barberton Greenstone Belt, South Africa. Geol. Soc.Am. Spec. Pap. 329, pp. 233-258.

McDonald, D., 1986. Proximal to distal sedimentological variation in a linear turbidite trough: implications for the fan model. Sedimentology 33, 243-259.

Nemec, W., Steel, R.J., 1988. What is a fan delta and how do we recognise it? In: Nemec, W., Steel, R.J. (Eds.), Fan Deltas: Sedimentology and Tectonic Settings. Blackie and Son, London, pp. 3-13.

Nijman, W., De Vries, S.T., 2004. Early Archaean crustal collapse structures and sedimentary basin dynamics. In: Eriksson, P.G., Altermann, W., Nelson, D.R., Mueller W.U., Catuneanu, O. (Eds.), The Precambrian Earth: Tempos and Events. Developments in Precambrian Geology, vol. 12. Elsevier, pp. 139-155.

Nijman, W., Willigers, B.J.A., Krikke, A., 1998/1999. Tensile and compressive growth structures: relation between sedimentation, deformation and granite intrusion in the Archaean Coppin Gap Greenstone belt, Eastern Pilbara, Western Australia. Precambrian Res. 88, 83-107 (Erratum re-edition in 1999, Precambrian Res., 95, 277-302)

Pike, G., Cas, R., 2002. Stratigraphic evolution of Archaean volcanic rock-dominated rift basins from the Whim Creek Belt, west Pilbara Craton, Western Australia. In: Altermann, W., Corcoran, P.L. (Eds.), Precambrian Sedimentary Environments: A modern Approach to Ancient Depositional Systems. Spec. Publs. Int. Ass. Sediment., 33, pp. 213-234.

Rodriguez-Lopez, J.P., Melendez, N., de Boer, P.L., Soria, A.R., 2010. The action of wind and water in a mid-Cretaceous subtropical erg-margin system close to the Variscan Iberian Massif, Spain. Sedimentology, doi:10.1111/j.13653091.2010.01147.x.

Smithies, R.H., Nelson, D.R., Pike, G., 2001. Development of the Archaean Mallina basin. Pilbara Craton, northwestern Australia; a study of detrital and inherited zircon ages. Sediment. Geol. 141/142, 79-94.

Thom, R., Hickman, A.H., Chin, R.J., 1973. Nullagine, Sheet SF 51-5. Western Australia Geological Survey, 1:250000 Geological Series.

Thorpe, R.I., Hickman, A.H., Davis, D.W., Mortensen, J.K., Trendall, A.F., 1992. Constraints to models for lead evolution from precise zircon U/Pb geochronology for the Marble Bar region, Pilbara Craton, Western Australia. In: Glover, J.E., Ho, S.E. (Eds.), The Archaean: Terrains, Processes and Metallogeny. Geol. Dept. and Univ. Ext., The Univ. of W. Austr. Publ. 22, pp. 395-406.

Tyler, I.M., Fletcher, I.R., 1992. Isotope and rare earth element evidence for a late Archaean terrane boundary in the southeastern Pilbara Craton, Western Australia. Precambrian Res. 54, 211-229.

Van Kranendonk, M.J., Hickman, A.H., Smithies, R.H., Nelson, D.N., Pike, G., 2002. Geology and tectonic evolution of the Archaean North Pilbara terrain, Pilbara Craton, Western Australia. Econ. Geol. 9, 695-732.

Van Kranendonk, M.J., Collins, W.J., Hickman, A., Pawley, M.J., 2004. Critical tests of vertical vs. horizontal tectonic models for the Archaean East Pilbara Granite-Greenstone Terrane, Pilbara Craton, Western Australia. Precambrian Res. 131, 173-211.

Van Kranendonk, M.J., Hickman, A.H., Smithies, R.H., Williams, I.R., Bagas, L., Farrell T.R., 2006. Revised lithostratigraphy of Archean supracrustal and intrusive rocks in the Northern Pilbara Craton, Western Australia. Western Australia Geological Survey, Record 2006/15, 57 pp.

Van Kranendonk, M.J., Smithies, R.H., Hickman, A.H., Champion, D.C., 2007. Review: Secular tectonic evolution of Archean continental crust: interplay between horizontal and vertical processes in the formation of the Pilbara Craton, Australia. Terra Nova 19, 1-38.

Wellman, P., 2000. Upper crust of the Pilbara Craton, Australia; 3D geometry of a granite/greenstone terrain. Precambrian Res. 104, 175-186.

Williams, I.R., 1999, Geology of the Muccan 1:100000 Sheet. Western Australia Geological Survey, 1:100 000 Geological Series Explanatory Notes, 39 pp.

Williams, I.R., Hickman, A.H., 2007. Nullagine, Sheet SF 51-05 (3rd edition). Western Australia Geological Survey, 1:250 000 Geological Series.

Wingate, M.T.D., 1999. Ion microprobe baddeleyite and zircon ages for Late Archaean mafic dykes of the Pilbara Craton, Western Australia. Aust. J. Earth Sci. 46, 493-500.

Zegers, T.E., White, S.H., De Keijzer, M., Dirks, P., 1996. Extensional structures during deposition of the 3460 Ma Warrawoona Group in the eastern Pilbara Craton, Western Australia. Precambrian Res. 80, 89-105.

Zegers, T.E., Barley, M.E., Groves, D.I., McNaughton, N.J., White, S.H., 2002. Deformation and hydrothermal alteration in the Early Archean Shear zone-hosted Bamboo Creek Deposit, Pilbara, Western Australia. Econ. Geol. 97, 757773. 